\title{
Modeling effects of tidal and wave mixing on circulation and thermohaline structures in the Bering Sea: Process studies
}

\author{
Haoguo $\mathrm{Hu}^{1}$ and Jia Wang ${ }^{2}$ \\ Received 29 October 2008; revised 26 June 2009; accepted 11 September 2009; published 19 January 2010.
}

[1] Ocean circulation and the tidal current in the Bering Sea are simulated simultaneously using a coupled ice-ocean model (CIOM) with tidal and parameterized wave mixing to investigate several important physical processes. The simulated circulation pattern in the deep basin is relatively stable, cyclonic, and has little seasonal change. The Bering Slope Current is estimated at $5 \mathrm{~Sv}$ and the Kamchatka Current at $20 \mathrm{~Sv}$. The modeled volume transports through the Aleutian passes compared reasonably well with observations. It is confirmed that subtidal clockwise circulation around St. George and St. Paul islands are driven by tidal rectification. The simulation results show that wind-wave mixing and tidal stirring are the main factors controlling the formation of the upper and the bottom mixed layers, respectively. The mechanism of thermocline and the cold pool (summer minimum-temperature water) formation in the middle shelf are investigated in depth. The CIOM reproduces the cold winter-convective water in the middle shelf that forms the bottom cold pool, which persists throughout the summer until sea surface cooling and strong wind mixing in fall, leading to an unstable vertical water column and eventually to vertically well-mixed water in the winter. Sensitivity experiments show that tidal and wind-wave mixing are two important factors in accurately estimating the volume of the cold pool, which is the ideal marine habitat for cold water species.

Citation: Hu, H., and J. Wang (2010), Modeling effects of tidal and wave mixing on circulation and thermohaline structures in the Bering Sea: Process studies, J. Geophys. Res., 115, C01006, doi:10.1029/2008JC005175.

\section{Introduction}

[2] The Bering Sea is a semienclosed, subpolar sea, which is connected to the Arctic Ocean to the north, and bounded on the west by Siberia, Russia, on the east by Alaska, and on the south by the Aleutian Islands (Figure 1, model domain). Bowers Ridge (with a minimum depth of $184 \mathrm{~m}$ ) and Shirshov Ridge (with minimum depth of $500 \mathrm{~m}$ ) divide the Bering Sea into three basins-Bowers Basin, Kamchatka Basin, and Aleutian Basin. The Bering Sea is divided almost equally between deep basins and the continental shelves $(<200 \mathrm{~m})$. The broad shelf in the east dominated by ocean tides contrasts with the narrow shelf in the west. The steep bathymetric features include the deep Aleutian Trench $(>5500 \mathrm{~m})$ and the Bering Basin $(>3500 \mathrm{~m})$ and the relatively shallow Bering Sea Shelf and Aleutian Islands chain $(<100 \mathrm{~m})$.

[3] The circulation pattern (Figure 2; after Stabeno et al. [1999]) in the deep Bering Sea basin is described as a

\footnotetext{
${ }^{1}$ Cooperative Institute for Limnology and Ecosystems Research, School of Natural Resources and Environment, University of Michigan, Ann Arbor, Michigan, USA.

${ }^{2}$ Great Lakes Environmental Research Laboratory, NOAA, Ann Arbor, Michigan, USA.

Copyright 2010 by the American Geophysical Union. 0148-0227/10/2008JC005175\$09.00
}

cyclonic gyre: the Aleutian North Slope Current (ANSC) flows eastward along the Aleutian Islands; the Bering Sea Slope Current (BSC) flows northwestward, and the southward flowing Kamchatka Current forms the western boundary current. The currents on the Bering Sea shelf are basically northward or northwestward [Kinder and Schumacher, 1981b].

[4] Since measurements are not sufficient to determine the seasonal circulation variation and cannot represent the whole domain with sufficient spatial coverage, models with realistic settings can help to derive more detailed information about the general circulation in the Bering Sea. Overland et al. [1994] used a three-layer hydrodynamic model to simulate the circulation of the Bering Sea Basin, while the Bering Sea shelf and slope regions shallower than $500 \mathrm{~m}$, hence the cross-shelf flux, were excluded from the model.

[5] A regional eddy-resolving ocean only model, which included both tidal and subtidal dynamics, was implemented at $4 \mathrm{~km}$ grids in the southeastern Bering Sea to simulate circulation on the southeastern Bering Sea shelf and basin [Hermann et al., 2002]. This model resolved the dominant observed mean currents, eddies, and meanders in the region. Circulation, temperature, and salinity fields for 1995 and 1997 were hindcast, using daily wind and buoyancy flux, and tidal forcing derived from a global model. These hindcast results compared favorably with conductivity-temperature-depth (CTD) data sections, 


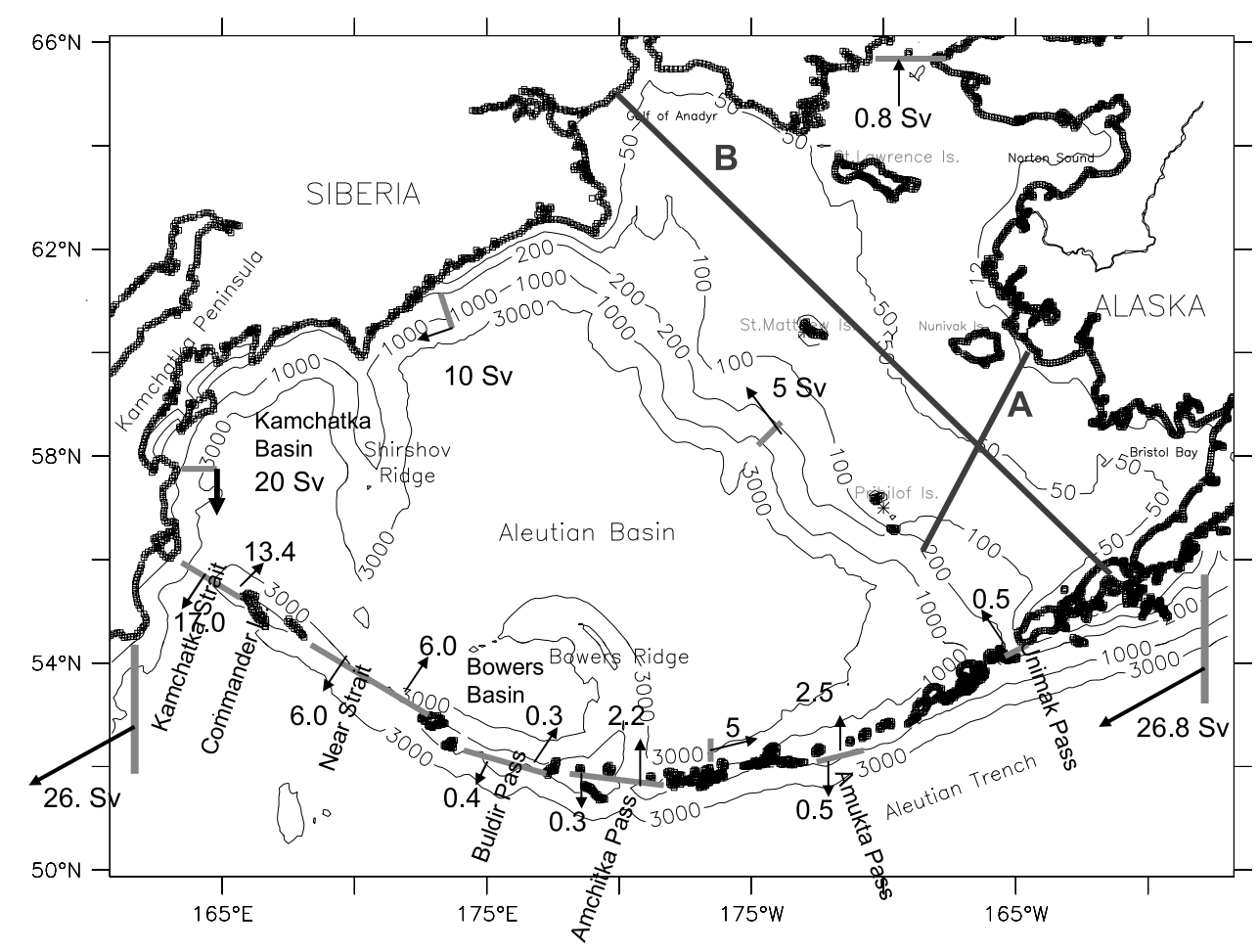

Figure 1. The model domain, bathymetry, and topography (in meters) of the Bering Sea. The depths along the Aleutian passes are modified according to NOAA ocean charts. Transects A and B are shown for model-data comparison. The shown transects are for calculating volume transports through the Aleutian passes, Alaskan Current, Kamchatka Current, and Bering Strait. Model-simulated annually averaged volume transports are also shown (see section 3.1, Figure 5, and Table 2): Arrows indicate flow directions. Numbers indicate transports in Sverdrups. The transport of the Bering Slope Current is $5 \mathrm{~Sv}$ by integrating from 200 to $1000 \mathrm{~m}$ isobaths versus 3 to $6 \mathrm{~Sv}$ [Stabeno et al., 1999]. The transport of the Kamchatka Current is $20 \mathrm{~Sv}$ by integrating from the coast to $3000 \mathrm{~m}$ isobaths. The transport of the Aleutian North Slope Current is $5 \mathrm{~Sv}$ by integrating from the Aleutian Islands to $2000 \mathrm{~m}$ isobaths and is $10 \mathrm{~Sv}$ by integrating from islands to $3000 \mathrm{~m}$ isobaths.

moored current meters, and drogued drifters. However, this model does not cover the entire Bering Sea, and no seasonal cycles were simulated. Furthermore, because no wave mixing was included, the simulated upper mixed-layer depth of $10 \mathrm{~m}$ is smaller than the observed value of $20 \mathrm{~m}$.

[6] Clement et al. [2005] use a $\sim 9 \mathrm{~km}$ pan-Arctic coupled ice-ocean model to investigate the Bering Sea ocean circulation and water exchange via the Bering Strait. Interannual variability of sea ice cover, ocean eddy kinetic energy, and transport were examined. This modeling study provides much information in this area. Nevertheless, the study focuses mainly on ocean transports. The model does not include tides and wind-wave mixing, and the simulated summer upper surface mixed layer is less than $10 \mathrm{~m}$, which is very shallow compared to observations at $\sim 20 \mathrm{~m}$ [Kinder and Schumacher, 1981a].

[7] The mechanism of summer thermocline formation in the Bering shelf seems well understood from observations (i.e., by tidal stirring and surface wind-wave mixing; see Kinder and Schumacher [1981a], Schumacher and Stabeno [1998], and Kachel et al. [2002]); however, it is still difficult to be reproduced using a 3-D physical ocean model. Overland et al. [1999] used a 1-D model to hindcast the 1980 spring-summer thermal transition of the Bering Sea shelf as a function of water depth, but without horizontal processes. Kachel et al. [2002] developed a simple model on the basis of surface heat flux and water column mixing to explain the cold belt (i.e., cold pool) associated with such fronts. Both the Hermann et al. [2002] and Clement et al. [2005] models underestimate the mixed layer depth because they lack wind-wave mixing.

[8] Observations [Takenouti and Ohtani, 1974; Kinder and Schumacher, 1981a; Wyllie-Echeverria, 1995] show that the cold water (with a nickname of the "cold pool," whose temperature is $<2.0^{\circ} \mathrm{C}$ ) near the bottom in the middle shelf persists throughout the summer, and it was speculated that this cold water is formed locally in winter and insulated by strong stratification in summer.

[9] Wang et al. [2009] developed a $9 \mathrm{~km}$ Bering Sea coupled ice-ocean model (CIOM) to conduct a model-data fusion study on seasonal variations of sea ice and ocean circulation. They focused on (1) sea ice seasonal variation in comparison with satellite measurements, (2) two distinct summer and winter surface wind-driven circulation patterns in the middle shelf caused by the two opposite wind regimes, (3) summer upwelling along the Siberian coast, (4) seasonal properties along the $165^{\circ} \mathrm{W}$ line in comparison to the shipboard measurement, and (5) volume, heat, and salt transports 
along the $62.5^{\circ} \mathrm{N}$ line. Nevertheless, they did not investigate the major ocean current transports including the Aleutian throughflow transports, and some important dynamic and thermodynamic processes such as the mechanism for the cold pool formation and effects of tidal and wind-wave mixing on seasonal thermohaline structures.

[10] Thus, in this study, we extend the Bering-CIOM [Wang et al., 2009] to simulate the circulation and tidal current simultaneously and to estimate transports of major current systems including the throughflow along the Aleutian passes. We also attempt to improve the CIOM with parameterization of wind-wave mixing to reveal dynamic and thermodynamic processes in the Bering shelf. These processes include (1) wave mixing and tidal mixing and their impacts on the vertical temperature and salinity structure, (2) tidal-induced residual eddies around islands, and (3) the cold pool formation process.

[11] This paper is organized as follows: section 2 describes the model configuration, and section 3 discusses simulated circulation transports in comparison with available observations, including the effect of wind mixing and tidal mixing on vertical temperature structure, tidal-induced residual eddies, and the cold pool formation. Section 4 summarizes the conclusions and discusses future efforts.

\section{Description of the Bering CIOM}

[12] The Bering CIOM used here is the same version of Wang et al. [2009]. A detailed description of development of the CIOM can be found in the work of Yao et al. [2000] and Wang et al. [2002, 2005]; it was applied to the panArctic Ocean [Wang et al., 2004, 2005; Wu et al., 2004], the Beaufort Sea [Wang et al., 2003], and the Bering Sea [Wang et al., 2009]. The ice model used is a full thermodynamic and dynamics model [Hibler, 1979, 1980]. The ice model has full thermodynamics with one-layer ice and one-layer snow and full dynamics with viscous-plastic rheology [Hibler, 1979, 1980; Wang et al., 1994]. A multiple thickness category ice model [Thorndike et al., 1975; Hibler, 1980; Yao et al., 2000] was used, fully coupled to the ocean model [Mellor and Kantha, 1989]. In this study, eight ice categories $(0,0.1,0.2,0.5,1.0,1.5,2.5,4 \mathrm{~m})$ are used, each having a percentage in a grid point. Thus, the ice thickness equation for each category is calculated. Then, the summation of each category thickness is the total thickness at each grid. Thus, sea ice concentration and thickness at each grid are calculated from the sum of the eight ice categories. A parameterization for the lateral melting of sea ice [Ohshima and Nihashi, 2005] was implemented. The prognostic and diagnostic variables include sea ice velocity, thickness, sea ice concentration (SIC), ice edge, and heat and salt flux through sea ice into the ocean.

[13] The ocean model used here is the Princeton Ocean Model (POM) described in detail by Blumberg and Mellor [1987] and Mellor [2004]. It is a three-dimensional, primitive-equation, vertical $\sigma$-coordinate model with a curvilinear orthogonal horizontal grid using an Arakawa C-grid. Horizontal time differencing is explicit, whereas the vertical differencing is implicit; the latter eliminates time constraints for the vertical coordinate and permits the use of fine vertical resolution in the surface and bottom boundary layers. POM has a free surface with a second-order turbulence closure scheme [Mellor and Yamada, 1982] to calculate vertical mixing coefficients. Horizontal mixing coefficients employ the Smagorinsky [1963] parameterization [Mellor, 2004].

[14] Differing from Wang et al. [2005, 2009], in this study, we implement oceanic tides and wave mixing parameterization into the Bering-CIOM, as described as follows.

\subsection{Wave Mixing Parameterization}

[15] Ocean circulation models usually underestimate surface mixed layer depth, which is often too small during the spring-summertime warming and freshening, compared to observations [Martin, 1985], even using the 2.5 closure turbulence model. One major reason is that wind-wave mixing is not included. Craig and Banner [1994] used wave breaking as a surface diffusion boundary condition, which is proportional to $\mathrm{u}_{\tau}^{3}$, where $\mathrm{u}_{\tau}$ is the surface friction velocity. Mellor and Blumberg [2004] found that the Craig and Banner [1994] model does deepen the mixed layer in a 1-D calculation, and has a positive, but relatively small influence on the 3-D calculation. Ezer and Mellor [1997] proved that the absorption of shortwave radiation below the surface, because of the loss of surface heat, causes the upper layer to be less stable, increases mixing, and thus deepens the summertime mixed layer depth. Qiao et al. [2004] used a wave number spectral model [Yuan et al., 1991] to derive wave-induced mixing on the basis of a linear wave theory [Yuan et al., 1999]. In this paper, on the basis of the same wave-induced mixing theory as Yuan et al. [1999] and Qiao et al. [2004], we use a single typical linear wave to represent the wave spectrum to parameterize wave-induced mixing. The advantage of our parameterization is to use the same wave theory to derive a simple, practical mixing, without running a complicated wave number spectral model. The surface wave mixing is parameterized into the model following Hu et al. [2004]:

$$
K_{m w}=\frac{2 \nu^{2}}{g} \delta \beta^{3} W^{3} e^{\frac{g z}{32^{2}}}
$$

where $K_{m w}$ is the wave-induced mixing coefficient; $\beta$ is the wave age $(0<\beta<1$ for growing wave, and $\beta=1$ for mature wave), $\delta$ is the wave steepness ( $\delta=2 a / \lambda, a$ is the amplitude and $\lambda$ is the wavelength), $W$ is the wind speed, $z<0$ is the depth, $\nu=0.4$ is the von Kármán constant, and $\mathrm{g}$ is acceleration of gravity. The detailed derivation of the above formula based on wind wave theory is provided in Appendix A.

[16] A mature but not breaking wave is assumed in this study as $\beta=1.0, \delta=0.1$, then the wave mixing parameter becomes:

$$
K_{m w}=\frac{0.2 \nu^{2}}{g} W^{3} e^{\frac{g z}{W^{2}}}
$$

Heat diffusion coefficient $K_{h w}$ can be assumed equal to $K_{m w}$; but in general, heat diffusion is considered to be slower than momentum transfer. Thus, it is assumed $K_{h w}=$ $P K_{m w}$ where $P$ is an empirical constant depending on the 
Richardson number. Following the POM [Mellor, 2004], we set

$$
\begin{gathered}
K_{h w}=\frac{S_{H}}{S_{M}} K_{m w} \\
S_{H}\left[1-\left(3 A_{2} B_{2}+18 A_{1} A_{2}\right) G_{H}\right]=A_{2}\left(1-6 A_{1} / B_{1}\right) \\
S_{M}\left(1-9 A_{1} A_{2} G_{H}\right)-S_{H}\left[\left(18 A_{1}^{2}+9 A_{1} A_{2}\right) G_{H}\right. \\
=A_{1}\left(1-3 C_{1}-6 A_{1} / B_{1}\right)
\end{gathered}
$$

where $\left(A_{1}, B_{1}, A_{2}, B_{2}, C_{1}\right)=(0.92,16.6,0.74,10.1,0.08)$

$$
G_{H}=\frac{l^{2}}{q^{2}} \frac{g}{\rho_{0}}\left(\frac{\partial \rho}{\partial z}-\frac{1}{c_{s}^{2}} \frac{\partial p}{\partial z}\right)
$$

where $l$ is the turbulence mixing length scale, $c_{s}$ is the sound velocity, $\rho$ is the water density, $\rho_{0}$ is the reference water density, $P$ is the pressure, and $G_{H}$ is the Richardson number. $S_{M}$ and $S_{H}$ are the stability functions, relating to the Richardson number [Mellor, 2004].

[17] Therefore, a linear addition of wave-induced $K_{m w}\left(K_{h w}\right)$ and $K_{m}\left(K_{h}\right)$ that is calculated by the level 2.5 closure turbulence model is assumed to be the total vertical viscosity (diffusivity) coefficients. Thus, the total mixing coefficients are

$$
K_{m}^{\prime}=K_{m}+K_{m w} ; K_{h}^{\prime}=K_{h}+K_{h w}
$$

where $K_{h w}$ and $K_{m w}$ are derived and discussed in Appendix A.

\subsection{Tidal Mixing}

[18] Ocean circulation and tidal currents can be simulated separately. It is acceptable to simulate ocean circulation when the tidal currents are weak in the open ocean. However, the tidal currents are very strong in the Bering Sea Shelf compared to the circulation. Tidal energy accounts for $90 \%$ of the total energy [Kinder and Schumacher, 1981b; Kowalik, 1999], and the dominant tidal stirring should not be ignored in the Bering Sea Shelf. The open boundary conditions of velocities are given by

$$
V_{\text {total }}=V_{\text {circulation }}+\sum_{i=1}^{n}\left(V_{a}\right)_{i} \cos \left(\omega_{i} t+\theta_{i}\right)
$$

where $V_{a}$ is tidal current amplitude, $\theta$ is tidal current phase, $\omega$ is the tidal frequency, and $n$ is the number of tidal constituents. Tidal parameters from global tide model results [Lefevre et al., 2002] are interpolated linearly to the open boundary grids.

\subsection{Model Configuration}

[19] The horizontal grids have a spherical coordinate system with a resolution of $1 / 12^{\circ}$ longitude (about $9.3 \mathrm{~km}$ ) and $1 / 6^{\circ}$ latitude (from $10 \mathrm{~km}$ near the Aleutian Islands to $7.4 \mathrm{~km}$ in the Bering Strait.) There are $24 \sigma$ layers in the vertical $(\sigma=0,-0.008,-0.016,-0.031,-0.063,-0.125$, $-0.188,-0.250,-0.313,-0.375,-0.438,-0.500$, $-0.563,-0.625,-0.688,-0.750,-0.813,-0.875$,
$-0.938,-0.969,-0.984,-0.992,-0.996$, and -1 , where $\sigma=(\mathrm{z}-\eta) /(\mathrm{H}+\eta), \eta(\mathrm{x}, \mathrm{y})$ and $\mathrm{H}(\mathrm{x}, \mathrm{y})$ are the surface elevation and water depth). The vertical resolution is higher near the surface and the bottom for a better representation of the surface and bottom boundary layers. The model has split modes. The 2-D external mode uses a time step of $20 \mathrm{~s}$, and the 3-D internal mode uses a time step of $600 \mathrm{~s}$.

[20] The bathymetry is obtained from the 5 min resolution ETOP05 data; however the depths of the Aleutian passes are modified according to a NOAA ocean chart [National Oceanic and Atmospheric Administration (NOAA), 2001, 2003, 2004a, 2004b, 2004c, 2005]. The area-averaged climatological density field was subtracted before calculating pressure gradient terms so that density related errors are less than $10 \%$ of the mean flow, substantially less than other numerical errors [Mellor et al., 1994]. The above procedure is widely used in previous applications of $\sigma$-coordinate models [Ezer and Mellor, 1997; Ezer et al., 2002]. Smoothing of topography was conducted with the steep slopes; the maximum bottom slope allowed between two adjacent grid points is $\Delta \mathrm{H} / \mathrm{H}<0.1$. Maximum and minimum depths are set to 3000 and $10 \mathrm{~m}$, respectively. Upwind advection boundary conditions allow the advection of the monthly mean temperature and salinity into the model domain under inflow conditions. At the open boundaries, vertically averaged inflow/outflow was prescribed on the basis of observations and the principle of volume conservation [Wang and Mooers, 1998]. For the baroclinic velocities, Sommerfeld type radiation [Mellor, 2004] conditions were used.

[21] Volume transport of the Alaskan Stream has been described by direct and indirect measurement data. Cokelet et al. [1996] used vessel-mounted Acoustic Doppler Current Profiler (ADCP) measurements to obtain an Alaskan Stream transport of $24 \mathrm{~Sv}$ on the basis of an absolute reference for geostrophic currents (0/1500 db). Onishi and Ohtani [1999], using current-meter mooring data, show that the Alaskan Stream volume transport (referred to $3000 \mathrm{~m}$ ) is $27.5 \pm 6.5 \mathrm{~Sv}$. Reed and Stabeno [1999b] used CTD data to obtain a volume transport of $25 \mathrm{~Sv}$ (referred to the bottom). Therefore, the westward flowing Alaskan Stream was specified at the western open boundary with a transport of $26 \mathrm{~Sv}$ plus a radiation boundary condition. The eastern boundary inflow is $26 \mathrm{~Sv}$ plus a transport $(0.8 \mathrm{~Sv})$ that equals the northward outflow at the Bering Strait (Table 1).

[22] Observations since the 1940s show that the annual mean net northward transport is about $0.8 \mathrm{~Sv}$ in the Bering Strait (Table 1) [Coachman et al., 1975; Coachman and Aagaard, 1981, 1988; Roach et al., 1995; Woodgate and Aagaard, 2005; Woodgate et al., 2005], and seasonal variations exist with a larger transport in summer than in winter. Therefore, the outflow transport was specified according to the monthly mean of Table 1 . Note that Woodgate et al. [2005] mentioned that the monthly climatology is not a good way to estimate the Bering Strait outflow in any particular year, because the outflow strongly relates to the local wind that varies strongly from year to year. Because this study is to simulate the seasonal cycle, the climatological volume transport in the Bering Strait prescribed into our model should be reasonable for our purpose.

[23] The model was initialized with annual climatologic temperature and salinity data from the Polar Science Center 
Table 1. Observed Transport of Bering Strait ${ }^{\mathrm{a}}$

\begin{tabular}{|c|c|c|c|c|c|c|c|c|c|c|c|c|c|c|}
\hline Time & Reference & January & February & March & April & May & June & July & August & September & October & November & December & Mean \\
\hline $1941-1946$ & $\begin{array}{l}\text { Coachman } \\
\text { and Aagaard } \\
\text { [1981] }\end{array}$ & 0.60 & 0.50 & 0.46 & 0.59 & 0.86 & 1.24 & 1.56 & 1.62 & 1.35 & 0.99 & 0.80 & 0.69 & 0.95 \\
\hline 1964 & $\begin{array}{l}\text { Coachman et al. } \\
\text { [1975] }\end{array}$ & & & & & & & & 1.40 & & & & & \\
\hline 1967 & $\begin{array}{l}\text { Coachman et al. } \\
\text { [1975] }\end{array}$ & & & & & & & 0.50 & 1.80 & & & & & \\
\hline 1968 & $\begin{array}{l}\text { Coachman et al. } \\
\text { [1975] }\end{array}$ & & & & & & & 1.67 & & & & & & \\
\hline 1972 & $\begin{array}{l}\text { Coachman et al. } \\
{[1975]}\end{array}$ & & & & & & & & & 1.90 & & & & \\
\hline 1973 & $\begin{array}{l}\text { Coachman et al. } \\
\text { [1975] }\end{array}$ & & & & & & & & & & 1.40 & & & \\
\hline $1976-1977$ & $\begin{array}{l}\text { Coachman } \\
\text { and Aagaard } \\
\text { [1981] }\end{array}$ & 0.54 & 0.24 & 0.33 & 0.50 & 0.50 & 0.84 & & & 0.46 & 0.30 & 0.32 & 0.13 & \\
\hline $1976-1977$ & $\begin{array}{l}\text { Coachman } \\
\text { and Aagaard } \\
\text { [1981] }\end{array}$ & 0.78 & 0.54 & 0.57 & 0.72 & 0.75 & 0.95 & 1.10 & 1.00 & 0.78 & 0.70 & 0.72 & 0.62 & 0.77 \\
\hline $1990-1994$ & $\begin{array}{l}\text { Roach et al. } \\
\text { [1995] }\end{array}$ & 0.92 & 0.85 & 0.33 & 0.72 & 0.62 & 1.15 & 1.34 & 0.96 & 0.58 & 0.78 & 0.82 & 0.30 & 0.78 \\
\hline $1990-2004$ & $\begin{array}{l}\text { Woodgate et al. } \\
\text { [2005] }\end{array}$ & 0.40 & 0.60 & 0.70 & 0.80 & 1.20 & 1.30 & 1.10 & 1.00 & 0.70 & 0.60 & 0.70 & 0.50 & 0.80 \\
\hline Mean & & 0.65 & 0.55 & 0.48 & 0.66 & 0.79 & 1.10 & 1.22 & 1.28 & 0.93 & 0.77 & 0.67 & 0.45 & 0.80 \\
\hline
\end{tabular}

${ }^{\mathrm{a}}$ Given in $\mathrm{Sv}$, where $1 \mathrm{~Sv}=10^{6} \mathrm{~m}^{3} / \mathrm{s}$.

Hydrographic Climatology (PHC 3.0; see Steele et al. [2001]). The sea ice velocity, concentration, and thickness were set to zero. The model was spun up using June climatological temperature and salinity from Steele et al. [2001] and motionless ocean for the first six years under National Centers for Environmental Prediction (NCEP) reanalysis monthly thermodynamic forcing [Ladd and Bond, 2002], which were derived from the period 194897, and monthly wind stress averaged from NCEP daily winds for the period 1948-2007. At the surface, salinity, with freshwater flux forcing from precipitation minus evaporation $(P-E)$, is restored to the observed monthly salinity

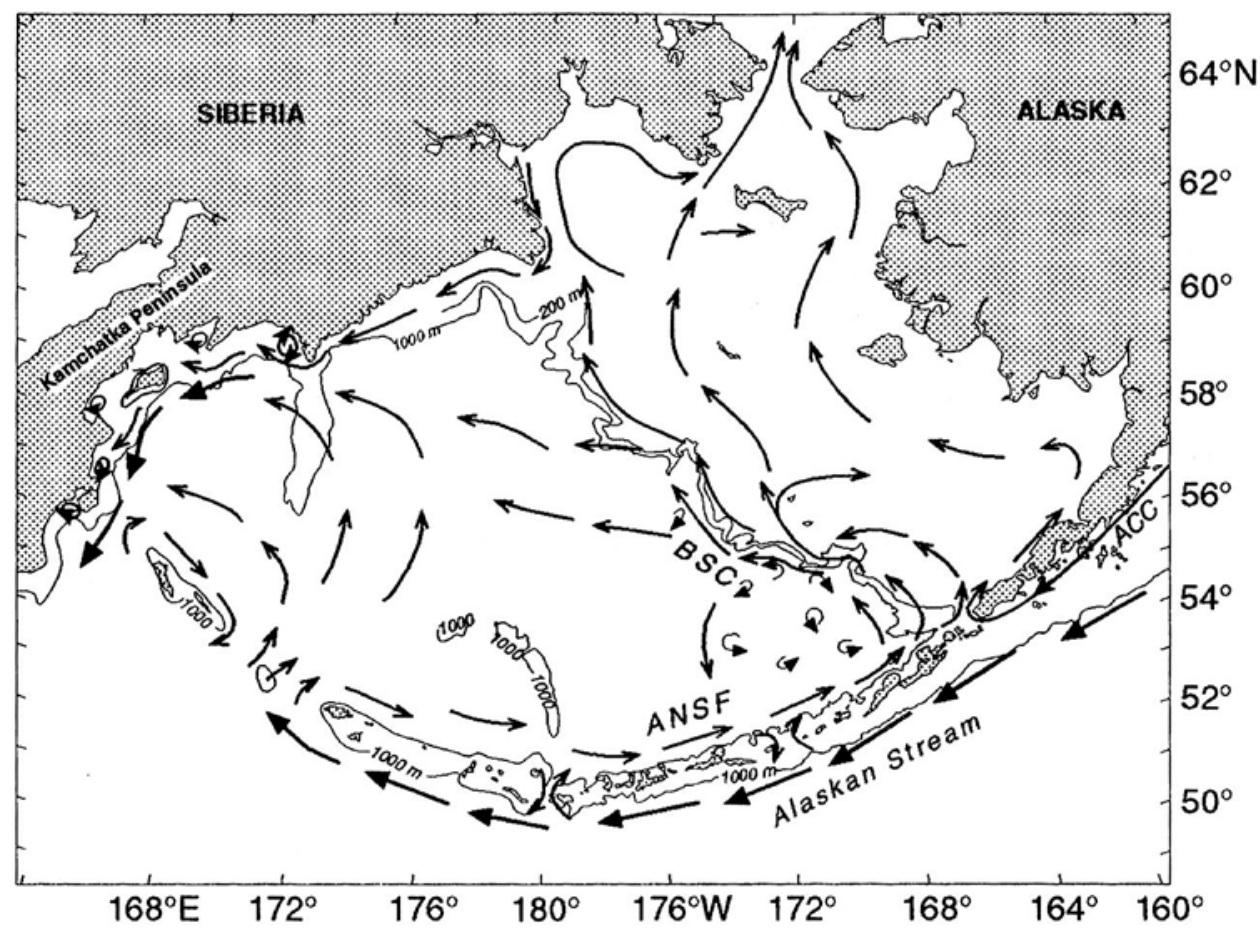

Figure 2. The schematic diagram for the surface circulation pattern in the Bering Sea based on historical observations (reproduced from Stabeno et al. [1999]). The Bering Slope Current (BSC) and the Aleutian North Slope Current or Front (ANSC or ANSF) are indicated. 


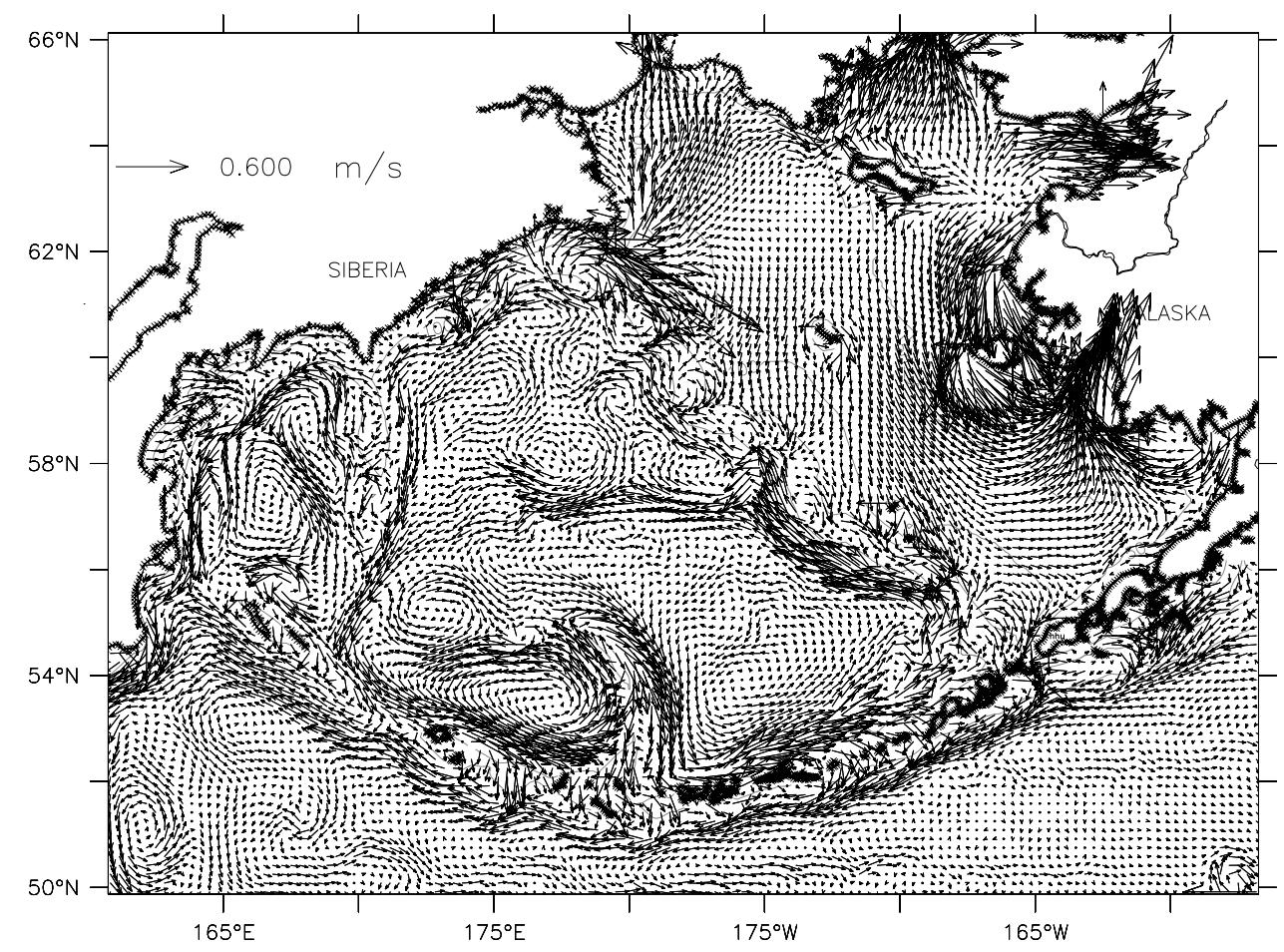

Figure 3. Model-simulated surface circulation (a snapshot in July) including ocean tidal currents. The vectors are drawn every four grids in longitude and every two grids in latitude.

fields for prescribing freshwater runoff using the flux correction method of Wang et al. [1994, 2001]:

$$
K_{H} \frac{\partial S}{\partial z}=Q_{S}+C\left(S_{O b s}-S\right), K_{H} \frac{\partial T}{\partial z}=\frac{Q_{H}}{\rho C_{P}}
$$

for salt and heat fluxes, where $\mathrm{C}$ is the restoring time constant $\left(5.79 \times 10^{-6} \mathrm{~m} \mathrm{~s}^{-1}\right)$ at a time scale of 30 days. At this rate, the modeled surface salinity (S) is adjusted (or restored) to the respective observed monthly values. $Q_{S}$ (in units of $\mathrm{m} \mathrm{s}^{-1}$ ) is the E-P or salt flux including freshwater runoff. $Q_{H}$ (in units of $\mathrm{Wm}^{-2}$ ) is the net surface heat flux calculated from the conventional ice-ocean budget [Wang et al., 2005].

[24] After a 6 year spin-up using NCEP monthly climatology, a dynamical and thermodynamical seasonal cycle is established, during which the total kinetic energy (TKE) achieves equilibrium, that is $\left(\mathrm{TKE}_{5 \mathrm{th}}-\mathrm{TKE}_{6 \mathrm{th}}\right) / \mathrm{TKE}_{6 \text { th }}<$ $1 \%$. Then, we re-ran the model for another four years using the previous sixth-year output as the restart or initial conditions. During the 4 year run, the climatological daily atmospheric forcings derived from the NCEP Reanalysis for the period 1948-2007 were used to drive the model. Then, the last year variables were used for examining the seasonal cycle in this study.

\section{Simulation Results: Process Studies}

\subsection{Estimate of Circulation Transport}

[25] The simulated currents (Figure 3, a snapshot in July) show that the tidal current dominates on the Bering Sea Shelf with the maximum tidal current being $>1 \mathrm{~m} \mathrm{~s}^{-1}$ and the directions varying periodically, while the current in the deep basin is relatively stable.
[26] The tidal-filtered summer circulations (Figure 4a) are similar to the observed circulation pattern (see Figure 2). The annually averaged volume transports were calculated and depicted in Figure 1. The Alaskan Stream flows westward along the Aleutian Islands and enters the Bering Sea via the Aleutian passes. The Aleutian North Slope Current (ANSC) flows eastward from Amchikta Island to Unimak Island, which is well documented, and the transport was estimated to be 2-4 Sv on the basis of satellite-tracked drifting buoys and geostrophic flow referred to $500 \mathrm{db}$ [Reed and Stabeno, 1999a]. The modeled transport of the ANSC is $2.5 \mathrm{~Sv}$ if the integration is conducted from the islands to $500 \mathrm{~m}$ isobath, $5 \mathrm{~Sv}$ from the islands to the $2000 \mathrm{~m}$ isobath, and it increases to $10 \mathrm{~Sv}$ from the islands to the $3000 \mathrm{~m}$ isobath (Figure 1). Note that Johnson et al. [2004] estimated the ANSC transport of $7 \mathrm{~Sv}$ using Argo floats.

[27] The simulated ANSC turns northwestward and flows along the 1000-3000 $\mathrm{m}$ isobaths to form the Bering Slope Current (BSC). The BSC becomes wider at $175^{\circ} \mathrm{W}, 56^{\circ} \mathrm{N}$ and bifurcates into two branches, which is consistent with historic reports (see Figure 2): one branch flows westward into the Aleutian Basin and contributes to northwest Aleutian Basin gyres; the other branch flows along the 1000-3000 m isobaths to the slope of Kamchatka. The simulated transport of BSC with integration from $200 \mathrm{~m}$ to $1000 \mathrm{~m}$ isobaths is about $5 \mathrm{~Sv}$ (Figure 1). Note that the transport increases to $10 \mathrm{~Sv}$ if the integration is extended to $2000 \mathrm{~m}$. Johnson et al. [2004] estimated a geostrophic transport of $5.8( \pm 1.7)$ Sv between 0 and 1900 dbar on the basis of CTD data, and Stabeno et al. [1999] concluded that the BSC transport is 3-6 Sv based on historical observations.

[28] In the Kamchatka Basin, the model simulation shows that there are several large clockwise and anticlockwise 


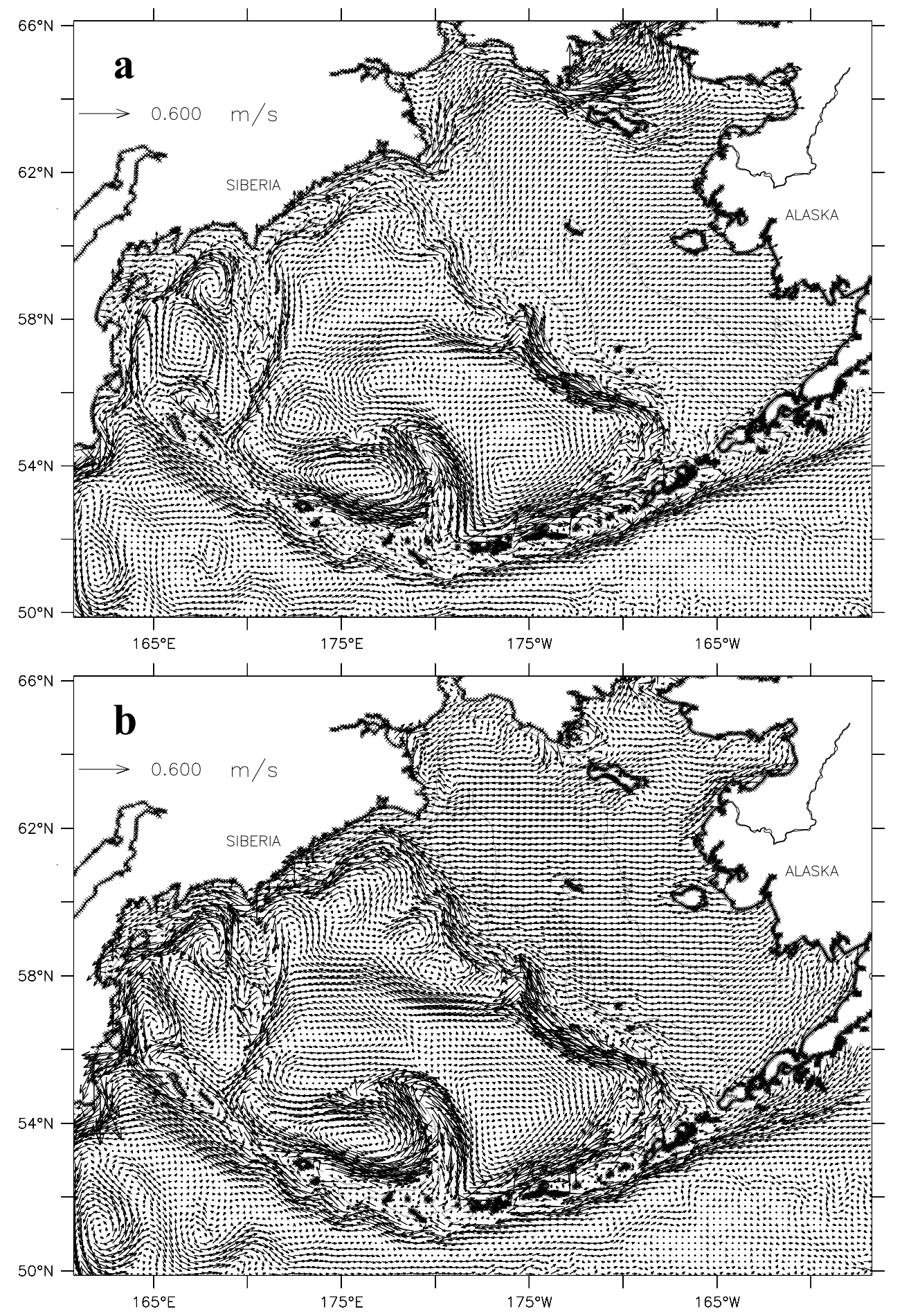

Figure 4. Model-simulated, tidal-filtered, 30-day-averaged surface circulation in (a) July and (b) February. The vectors are drawn every four grids in longitude and every two grids in latitude. The contour lines indicate bathymetry of 50,100,200, and $1000 \mathrm{~m}$.

eddies (Figure 4a) owing to baroclinic instability [Wang and Ikeda, 1997; Mizobata et al., 2006]. The counter-rotating eddy pairs were observed by Cokelet et al. [1996, sections 7 and 8] using ADCPs and satellite-tracked drifting buoys. The transport of the Kamchatka Current integrated from coast to $3000 \mathrm{~m}$ isobath is about $20 \mathrm{~Sv}$ (see Figure 1), consistent with the data-assimilated model estimate of 14-24 Sv by Panteleev et al. [2006].
[29] A current with an order of $1.0 \mathrm{~Sv}$ along the east coast of Siberia flows northeastward in summer clinging to the coast, passes around Cape Navarin, and enters the Gulf of Anadyr. The clockwise current exits the Gulf from Anadyr Strait, and finally flows to the Bering Strait (Figure 4a), which was confirmed by the measured currents from moorings in the Gulf of Anadyr during the summers from 1985 to 1988 [Coachman, 1993], and by the observed temperature, salinity, 


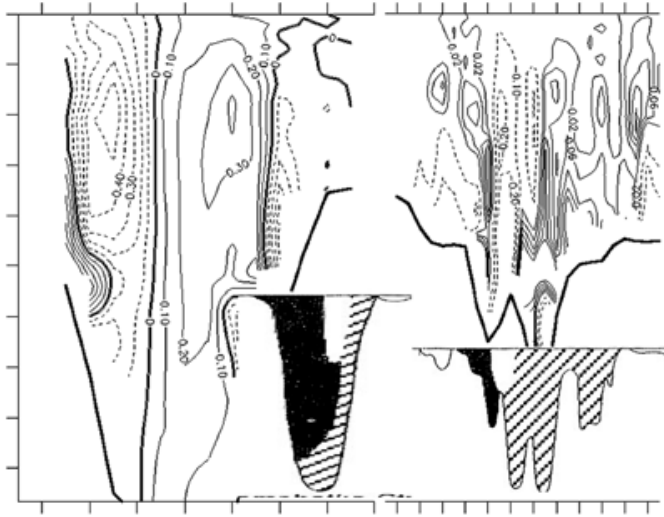

Kamchatka Strait
Near Strait

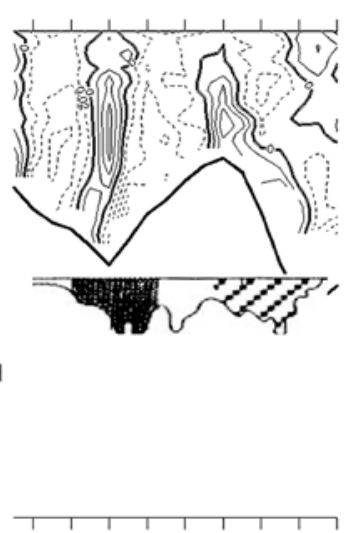

Buldir Pass

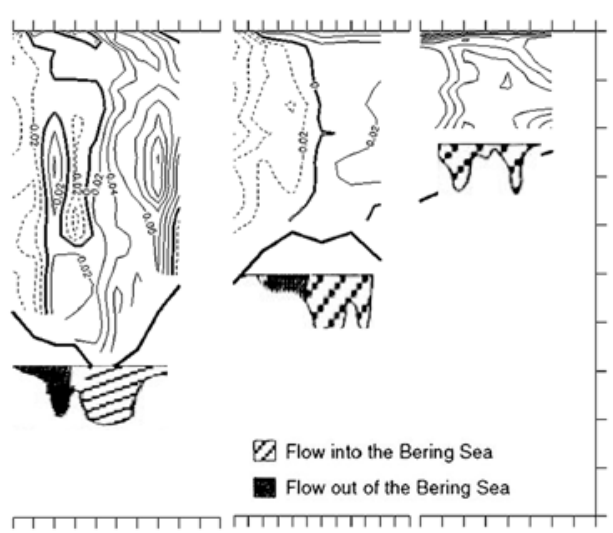

Amchitka Pass Amukta Pass Unimak Pass

Figure 5. Model-simulated flow structures of the Aleutian Passes, in which the solid/dashed lines indicate northward/southward flow, compared to the observations, in which the hatched/shaded regions indicate northward/southward flow (reproduced from Stabeno et al. [1999]).

drifter buoys [Overland et al., 1996], and the summer nitrate concentration [Springer et al., 1996]. However, this current is weak or even reverses to southward in winter owing to a strong northerly wind (see Figure 4b). Note that the measured vertical-averaged current during winter 1984-1985 shows the northward flow through Anadyr Strait is persistent in winter [Muench et al., 1988].

[30] The winter circulation pattern (Figure 4b) is similar to that in summer in the deep basins, except that the current in the Gulf of Anadyr is weaker (about $5 \mathrm{~cm} / \mathrm{s}$ ) than in summer (about $10 \mathrm{~cm} / \mathrm{s}$ ), and the shelf current is stronger in winter than in summer. There are two distinct shelf circulation patterns on the Bering shelf: northward to northeastward in summer and westward to southwestward in winter [Wang et al., 2009].

[31] The Aleutian passes play a primary role in determining water and material exchanges between the Bering Sea and the North Pacific Ocean [Stabeno et al., 2005; Mizobata et al., 2008]. Some measurements of volume transports through these passes were conducted using CTD, ADCP, buoy, and current meter moorings. Nevertheless, the results vary widely (Table 2 ) depending on both the type of data sets and the calculating methods. A notable feature is that both observations and simulated results show that water may enter and exit the passes at the same time (Figure 5).
[32] The Kamchatka Strait is the deepest strait and has the largest inflow and outflow in the Bering Sea. The measurements of net transport out of the Bering Sea range from 18.4 Sv [Favorite, 1974] to $6.8 \mathrm{~Sv}$ [Stabeno and Reed, 1992], while our simulated result shows an outflow of $17 \mathrm{~Sv}$ on the western side and an inflow of 13.4 Sv on the eastern side of the Kamchatka Strait. The Near Strait is the second largest pass contributing to water exchange between the North Pacific Ocean and the Bering Sea, the observed net transport ranges from 3 to $10 \mathrm{~Sv}$; our simulation shows that the inflow of $6 \mathrm{~Sv}$ is equal to the outflow, differing from the observations; Cokelet et al. [1996] estimated an inflow of $12 \mathrm{~Sv}$ and an outflow of $9 \mathrm{~Sv}$, resulting in a net inflow of $3 \mathrm{~Sv}$. Measurements have shown that the net transport through Amchitka is variable, ranging from $0.8 \mathrm{~Sv}$ to $2.8 \mathrm{~Sv}$; our simulated results give a net transport of $1.9 \mathrm{~Sv}$ into the Bering Sea. This transport, along with the inflow through the Amukta Pass, is one of the sources to the ANSC. Measurements show that the net transport through Amukta ranges from $0.8 \mathrm{~Sv}$ to $4 \mathrm{~Sv}$, while the simulated results give a net transport of $2.0 \mathrm{~Sv}$ into the Bering Sea.

[33] Table 2 and Figure 5 summarize that a basic feature captured by the measurements and the model is that the inflow/outflow occurred on the right/left side of a pass,

Table 2. Observed and Simulated Transports of the Aleutian Passes ${ }^{\mathrm{a}}$

\begin{tabular}{|c|c|c|c|c|c|c|c|c|}
\hline Time & Method & Reference & Kamchatka & Near & Buldir & Amchitka & Amukta & Unimak \\
\hline 1967 & cruise & Favorite [1974] & -18.4 & 10.0 & & & & \\
\hline Mar-Aug 1980 & mooring & Schumacher et al. [1982] & & & & & & $12 \mathrm{~cm} / \mathrm{s}$ \\
\hline Jun 1987 to Jun 1988 & mooring & Reed and Stabeno [1990] & & & 2.3 & & & \\
\hline 1990 & buoy & Stabeno and Reed [1992] & -6.8 & 4.9 & -2.8 & & & \\
\hline 1990 & CTD & Verkhunov and Tkachenko [1992] & -11 to -6 & & & & & \\
\hline Sep 1991 to Sep 1992 & mooring & Reed and Stabeno [1993] & & 5.0 & 1.0 & 0.8 & & \\
\hline 1993 & CTD & Reed and Stabeno [1994] & & & & 2.8 & 0.8 & \\
\hline $1988-1993$ & buoy & Stabeno and Reed [1994] & 50 to $60 \mathrm{~cm} / \mathrm{s}$ & & & & & \\
\hline 1991 & $\mathrm{CTD} / \mathrm{ADCP}$ & Cokelet et al. [1996] & -14 & 3.0 & & & & \\
\hline 1995 & CTD & Reed and Stabeno [1997] & & & & & 0.6 & \\
\hline 1999 & review & Stabeno et al. [1999] & & & & & & 0.23 \\
\hline May 2001 to May 2003 & mooring/review & Stabeno et al. [2005] & $<-12$ & $>10$ & & -2.8 to 4.0 & 4.0 & 0.3 \\
\hline 2006 & assimilation & Panteleev et al. [2006] & -14 to -24 & & & & & \\
\hline This study & model & & -3.6 & 0.0 & 2.6 & 1.9 & 2.0 & 0.5 \\
\hline
\end{tabular}

${ }^{\mathrm{a}}$ Given in Sv; otherwise stated in $\mathrm{cm} / \mathrm{s}$. Positive/negative velocity/transport indicates northward/southward flow. The passes are indicated by the green lines in Figure 1. 


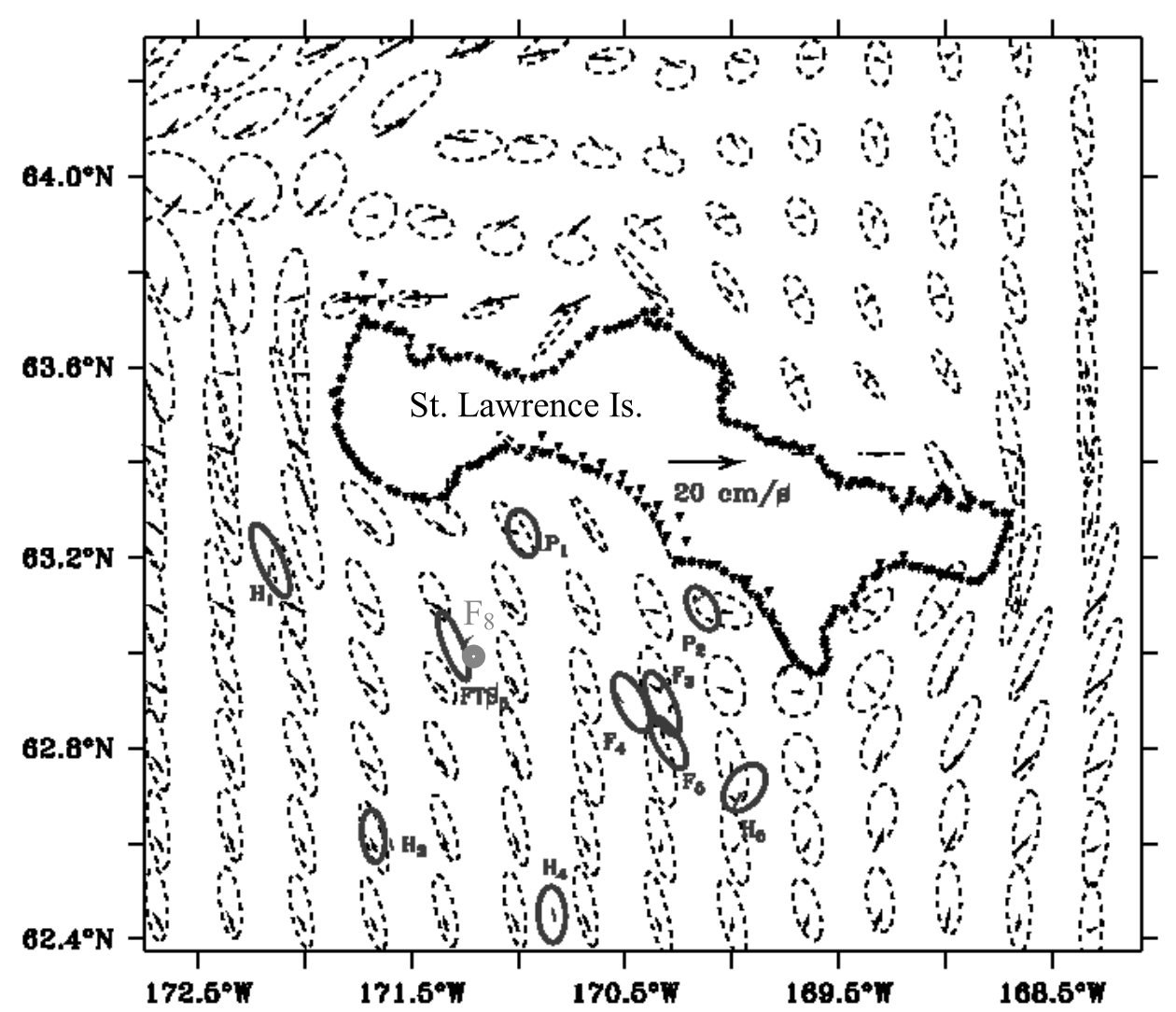

Figure 6. Yearly current (tidal currents plus circulation) ellipses. Mooring data are shown by solid lines (about $5 \mathrm{~m}$ above bottom; courtesy of S. Danielson and Z. Kowalik of the University of Alaska Fairbanks), and the simulated currents are shown by dashed lines (drawn every two grids). Arrows in the ellipses denote yearly averaged currents. The solid $\operatorname{dot}\left(\mathrm{F}_{8}\right)$ denotes a yearlong ADCP station.

except for the Unimak Pass, where a northward inflow dominates.

\subsection{Horizontal and Vertical Distribution of Tidal Currents}

[34] The coamplitude and cophase maps of $\mathrm{M}_{2}$ and $\mathrm{K}_{1}$ tides were constructed from the 3-D model [ $\mathrm{Hu}$ and Wang, 2008, Figures 3a and 3b], which compare very well with the 2-D tidal simulation by Kowalik [1999, Figures 3 and 6]. The difference between $\mathrm{M}_{2}$ and $\mathrm{K}_{1}$ tides is the latter is topographically trapped [Robinson, 1981; Zimmerman, 1978], such as along the Bering Slope and along Aleutian Islands, consistent with 2-D tidal simulation of Kowalik [1999].

[35] To further confirm that the Bering-CIOM can reproduce realistic tidal currents, we use 10 moorings for model-data comparison, which were deployed to collect ocean velocity data at hourly intervals over a 1 year period September 1998 to September 1999, as described by Danielson and Kowalik [2005]. The model simulations can be compared to the year-length current ellipses (Figure 6) south of St. Lawrence Island. The simulated semimajor axis of moored ellipse is approximately $15 \mathrm{~cm} / \mathrm{s}$, while the annually mean currents are only in order of $3-5 \mathrm{~cm} / \mathrm{s}$. This indicates the tidal currents are dominant on the Bering Shelf. Some discrepancies exist in a point-to-point comparison. The largest discrepancy is at stations $\mathrm{H}_{6}$ and $\mathrm{P}_{1}$ in both magnitude and direction. Many factors can result in the error such as model resolution, topographic data smoothing, atmospheric forcing, etc. In summary, the model reasonably reproduces tidal current and circulation in the region.

[36] The yearlong ADCP data at station $\mathrm{F}_{8}$ were analyzed by Danielson and Kowalik [2005, Figure 4]. Semidiurnal currents (Figure 7) dominate (approximately 4 times) over diurnal currents. $\mathrm{M}_{2}$ tidal currents are relatively constant from surface to about $15 \mathrm{~m}$, with a maximum around 20 $30 \mathrm{~m}$, and then decay quadratically to the bottom. This produces large vertical shear in the horizontal tidal currents. In contrast to the $M_{2}$ currents, the $K_{1}$ tidal currents (semimajor and semiminor axes) are invariant in the water column. The inclination and phase of $\mathrm{K}_{1}$ progress from the surface to the bottom in an opposite sense to the change of the $\mathrm{M}_{2}$ parameters. The model simulated vertical structures are qualitatively consistent with the measurements [see Danielson and Kowalik, 2005, Figure 4], except some errors in the inclination and phase, which may be due to the model resolution and depth smoothing. These errors should be significantly reduced if the mentioned error-causing factors are taken care.

\subsection{Tidal Effects on Subtidal Current and Eddies: A Validation Example}

[37] Satellite-tracked buoys deployed in 1993 and 1995 depicted circulation at the shelf break with tidal loops in the 

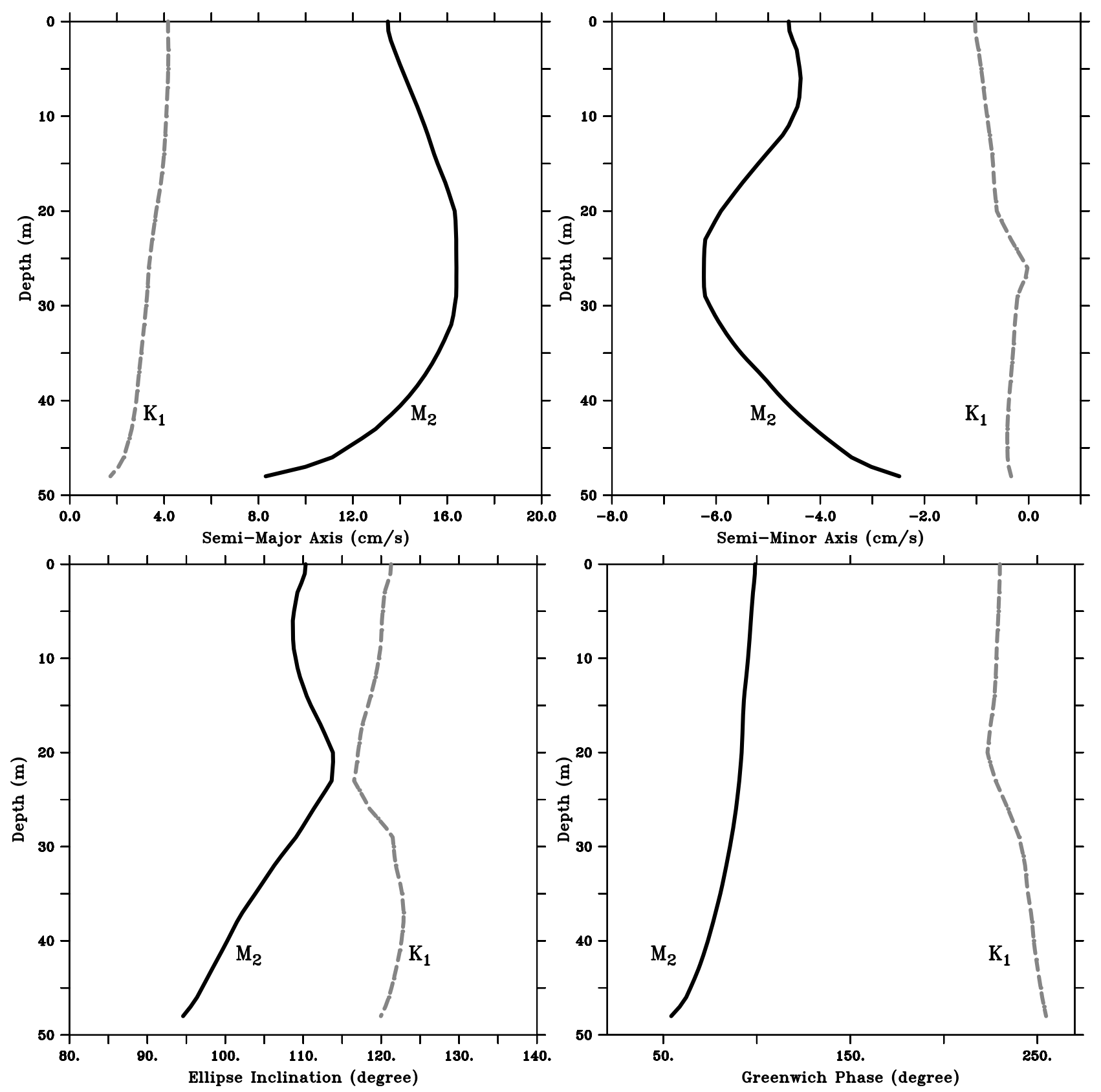

Figure 7. Model-simulated vertical structures of tidal currents at station $\mathrm{F}_{8}$ for $\mathrm{M}_{2}$ (solid lines) and $\mathrm{K}_{1}$ (dashed lines) tidal constituents. The positive (negative) sign of the semiminor axis denotes counterclockwise (clockwise) rotation. Top panels show the magnitude in $\mathrm{cm} \mathrm{s}^{-1}$, while lower panels show the phase in degrees.

region of the Pribilof Islands. The buoys were trapped in clockwise circulation (Figure 8a). Six current meters deployed around St. Paul Island revealed a steady clockwise flow around the island [Kowalik and Stabeno, 1999]. It is concluded that the mean tidal residual flow can be a major driving mechanism for the circulation and eddies around the islands.

[38] Two comparative experiments, without and with tides, were conducted for validating the tidal effects on the subtidal current. The circulation-only case (Figure $8 \mathrm{~b}$ ) shows a very weak $(1-2 \mathrm{~cm} / \mathrm{s})$ clockwise current around St. George Island, and it is not clockwise all the way around
St. Paul Island. When the tides and circulation are simulated simultaneously (Figure 8c), the tidal-filtered clockwise currents $(5-8 \mathrm{~cm} / \mathrm{s})$ around the St. Paul and St. George islands appear, which is similar to measurements of a $4-8 \mathrm{~cm} / \mathrm{s}$ clockwise current by Kowalik and Stabeno [1999]. The clockwise currents were also reproduced in a $4 \mathrm{~km}$ regional model [Hermann et al., 2002]. The Bering shelf subtidal currents are also modified in both magnitude and direction. This confirms tidal effects on rectifying the subtidal currents on the shallow shelf, which eventually affects the long-term material transport on the Bering shelf. 

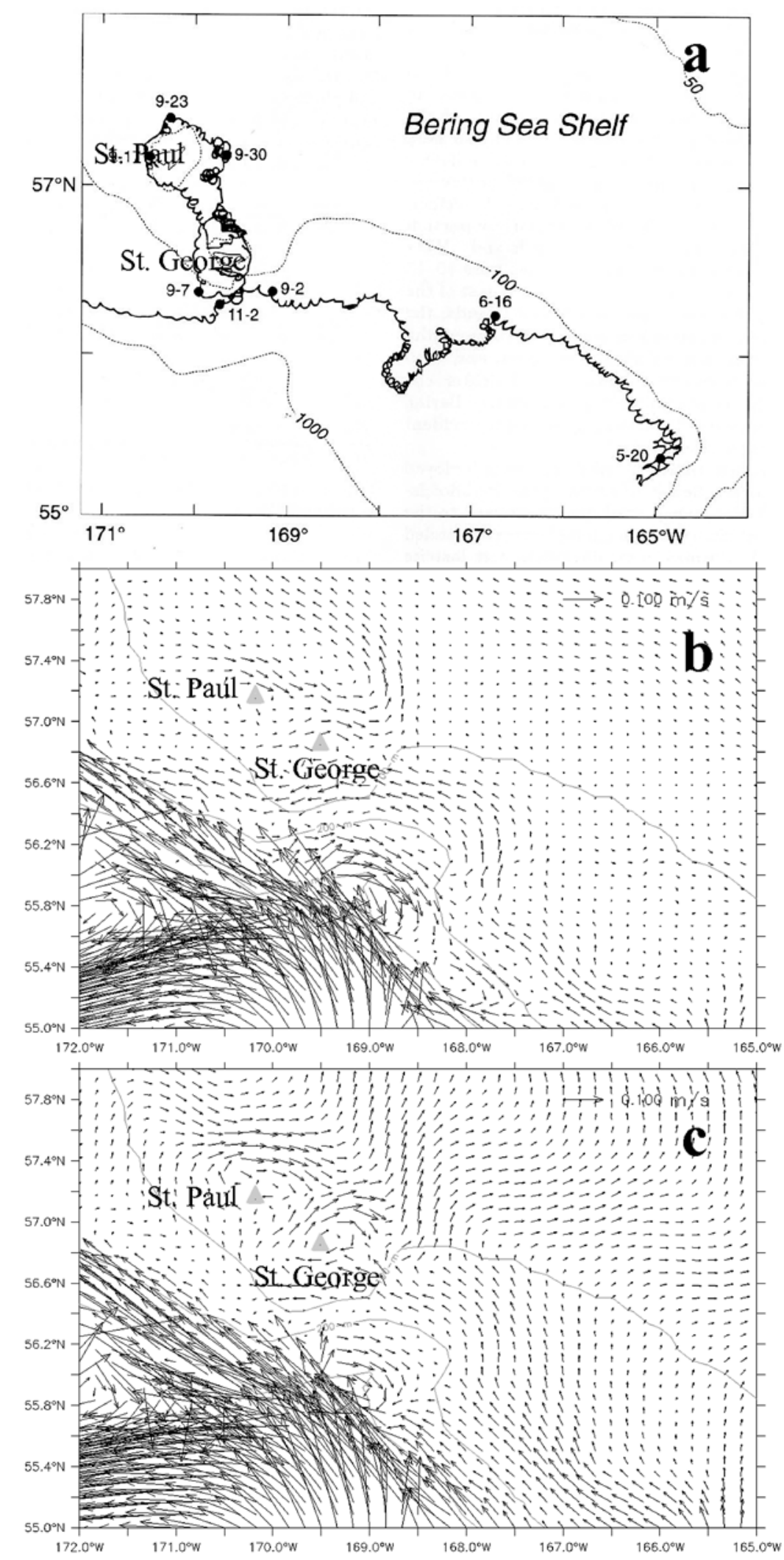

Figure 8. (a) Observed trajectories of two satellite-tracked drifting buoys from 20 May to 20 September 1995 (reproduced from Kowalik and Stabeno [1999]) and model-simulated, tidal-filtered subtidal current around the Pribilof Islands (b) without tides (circulations only) and (c) with tides (circulation and tides are simulated simultaneously). Isobaths of 100,200 , and $1000 \mathrm{~m}$ are shown in Figures $8 \mathrm{~b}$ and $8 \mathrm{c}$. The triangles show St. Paul and St. George islands because they occupy only one model grid. 


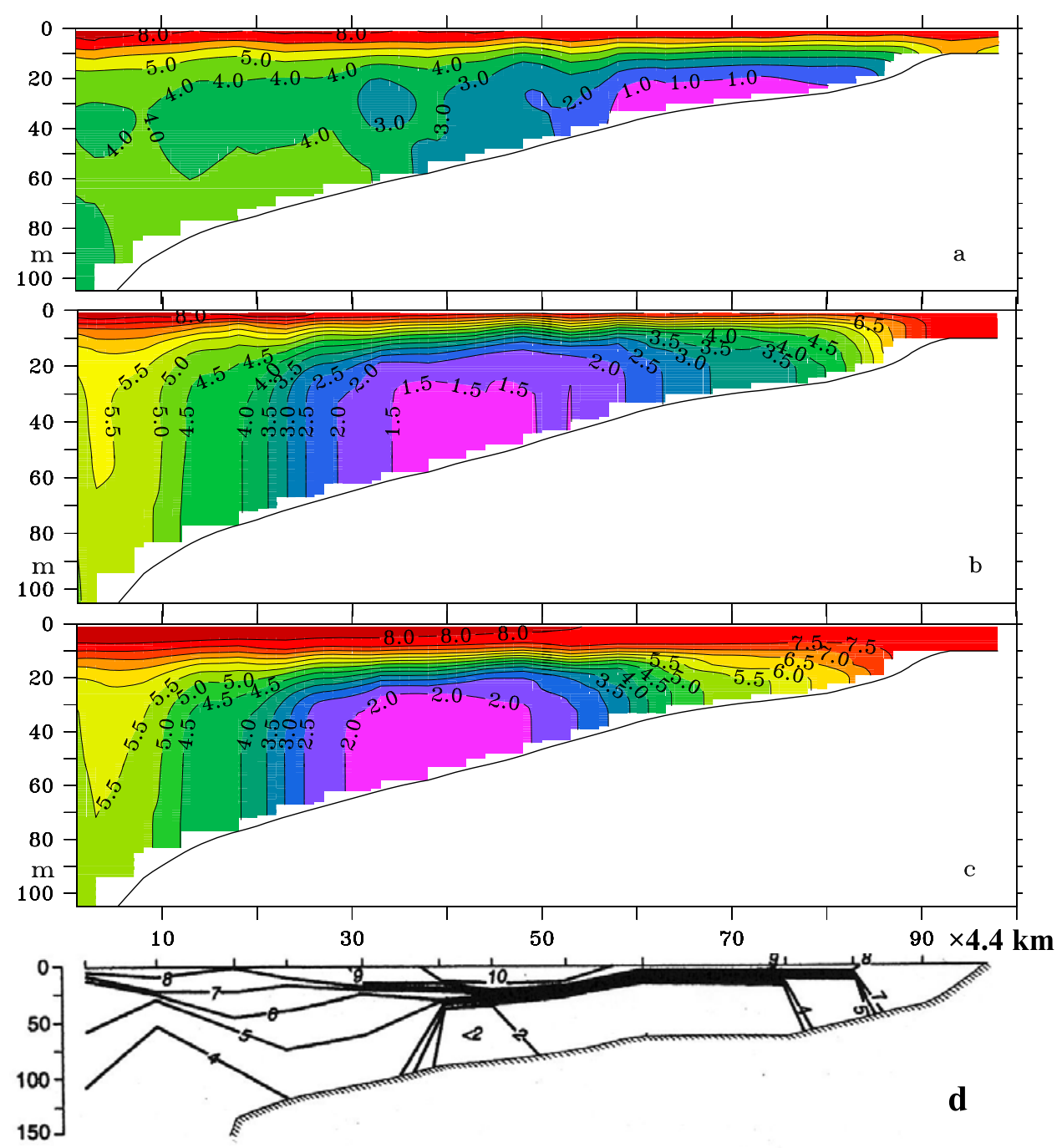

Figure 9. Model-simulated vertical temperature $\left({ }^{\circ} \mathrm{C}\right)$ structure in summer (July; see transect $\mathrm{A}$ in Figure 1, which is the same as that in the work of Kinder and Schumacher [1981a]). (a) Case 1: circulation only is simulated, isotherm at the surface layer is straight and flat, the depth of mixed layer is about $5 \mathrm{~m}$, and the thermocline is weak. (b) Case 2: the circulation and tides are simulated simultaneously, the bottom water is mixed to be homogenous, and the isotherm is lifted up. Vertical temperature has a dome-shaped structure, whereas the upper mixed layer is still shallow. (c) Case 3: when wave mixing is considered, the circulation and tidal current are simulated simultaneously; the upper mixed layer with a sharp-gradient thermocline layer between 10 and $30 \mathrm{~m}$ is well reproduced. (d) Observation (reproduced from Overland et al. [1999]).

\subsection{Effects of Tidal and Wind-Wave Mixing on Vertical Thermohaline Structures}

[39] Observations [Kinder and Schumacher, 1981b; Kachel et al., 2002] show that the thermocline exists throughout the summer, and wave mixing and tidal stirring are thought to play an important role in thermocline formulation and maintenance. We conducted three comparative experiments to verify the role of wind-wave mixing and tidal stirring on vertical temperature structure. Case 1 is the model run that simulates the ocean circulation only. In case 2 , the ocean circulation and tidal current are simulated simultaneously, and case 3 is the same as case 2, except that the wave mixing scheme introduced above is applied.

[40] In case 1, isotherms at the surface layer are flat (see Figure 9a and the section location on Figure 1, which is the same transect as the measurement of Kinder and Schumacher [1981a]). The upper mixed layer depth is about $5 \mathrm{~m}$, and the thermocline is weak. The cold water is located nearshore with a minimum temperature of $1.0^{\circ} \mathrm{C}$. The upper and the bottom mixed layers of salinity (Figure 10a) are not formed. The vertical eddy heat diffusion coefficient is approximately $10^{-5} \mathrm{~m}^{2} \mathrm{~s}^{-1}$ (Figure 11a), indicating the absence of both wind-wave mixing in the surface layer and tidal stirring in the bottom layer. Note without the surface wind-wave mixing, models driven even by daily wind forcing still underestimate mixing in the upper ocean, leading to a simulated mixed layer depth of $\sim 10 \mathrm{~m}$ [Hermann et al., 2002; Clement et al., 2005], compared to the observation of $\sim 20 \mathrm{~m}$. It is also noted that daily summer wind stress is much weaker than winter. 


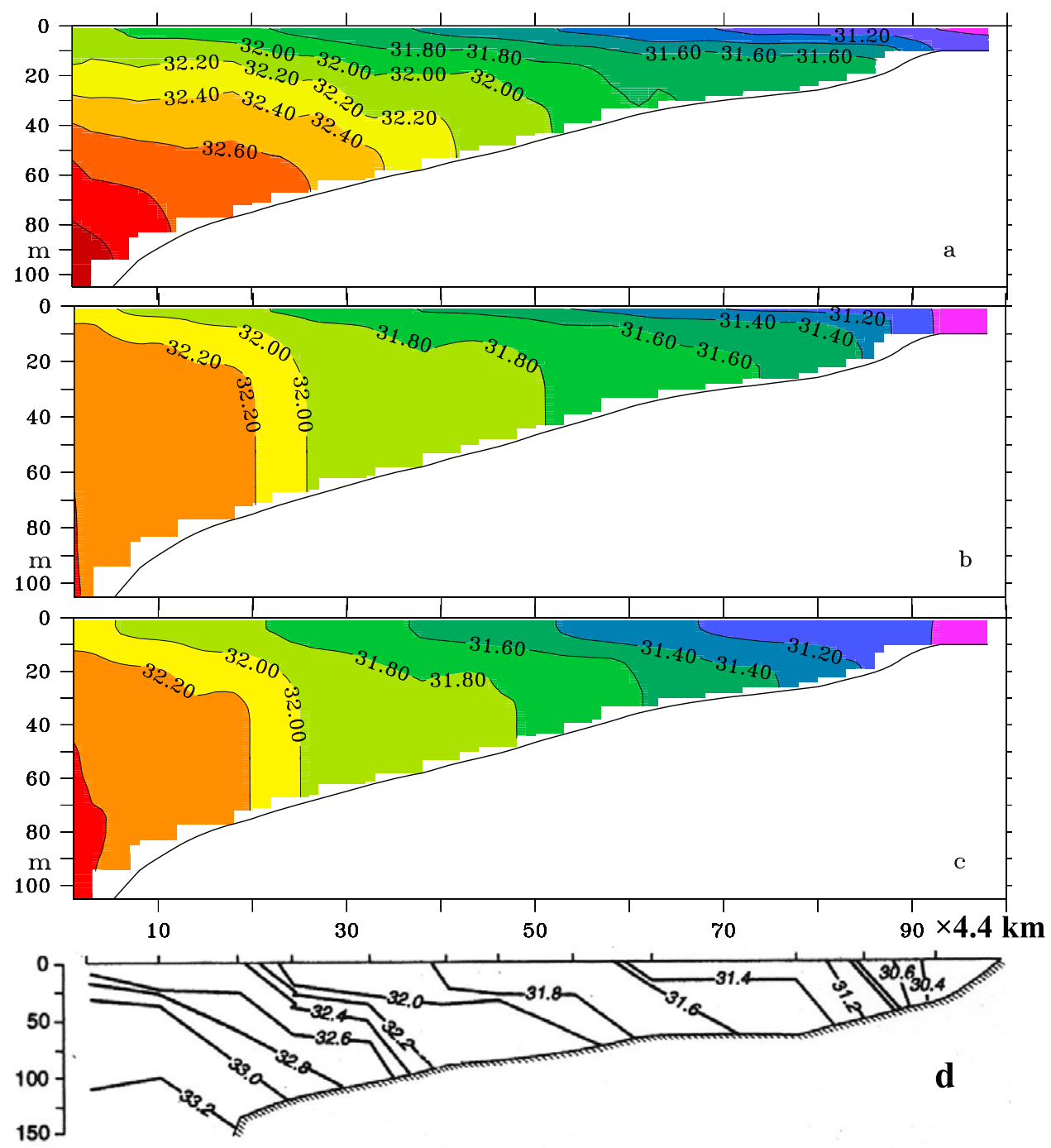

Figure 10. The same as in Figure 9, except for salinity (in practical salinity units). (a) Case 1: circulation only is simulated, isohalines are inclined seaward, and the upper and bottom mixed layers are not clear. (b) Case 2: the circulation and tides are simulated simultaneously, and the bottom water is mixed to be homogenous. (c) Case 3: when wave mixing is considered, the circulation and tidal current are simulated simultaneously; the upper and the bottom salinity are mixed to be homogenous. (d) Observation (reproduced from Overland et al. [1999]).

[41] In case 2, when the tidal currents are simulated simultaneously along with the ocean circulation, temperature and salinity in the bottom layer are mixed to be homogenous (Figures $9 \mathrm{~b}$ and $10 \mathrm{~b}$ ). Temperature in the bottom mixed layer increases to $1.5^{\circ} \mathrm{C}$. The vertical profile shows a dome-shaped structure. The cold water is now located farther offshore because of the strong tidal stirring in the nearshore region compared to the circulation-only case 1 . The bottom vertical eddy heat diffusion coefficient (Figure 11b) increases to an order of $10^{-2} \mathrm{~m}^{2} \mathrm{~s}^{-1}$, resulting in strong tidal mixing in the bottom boundary layer.

[42] In case 3, when the wind-wave mixing is included, the circulation and tidal current are simulated simultaneously. Temperature and salinity in the upper and the bottom layers are uniform (Figures $9 \mathrm{c}$ and 10c), and the temperature of the cold bottom water increases to $2.0^{\circ} \mathrm{C}$. The vertical eddy heat diffusion coefficient in the upper and bottom layers (Figure 11c) increases to an order of $10^{-2} \mathrm{~m}^{2} \mathrm{~s}^{-1}$. Away from the front (within the strongly stratified middle shelf domain), the thickness of the bottom mixed layer is nearly $50 \mathrm{~m}$, about the same thickness as the total water depth where the front is located. The thickness of the upper mixed layer is about $15-20 \mathrm{~m}$. A sharp vertical gradient occurs within the thermocline layer between 10 and $30 \mathrm{~m}$, which agrees well with the observations (see Figures 9d and 10d; after Kinder and Schumacher [1981a]). Note that the thermocline is still less sharp than the often observed. This seems to be a problem with all the models; that is, the inability to maintain a thermocline of $<4 \mathrm{~m}$. Such a less sharp boundary between the upper and lower layer on the middle shelf tends to result in too much mixing in the models and thus leads to a loss of stratification. 


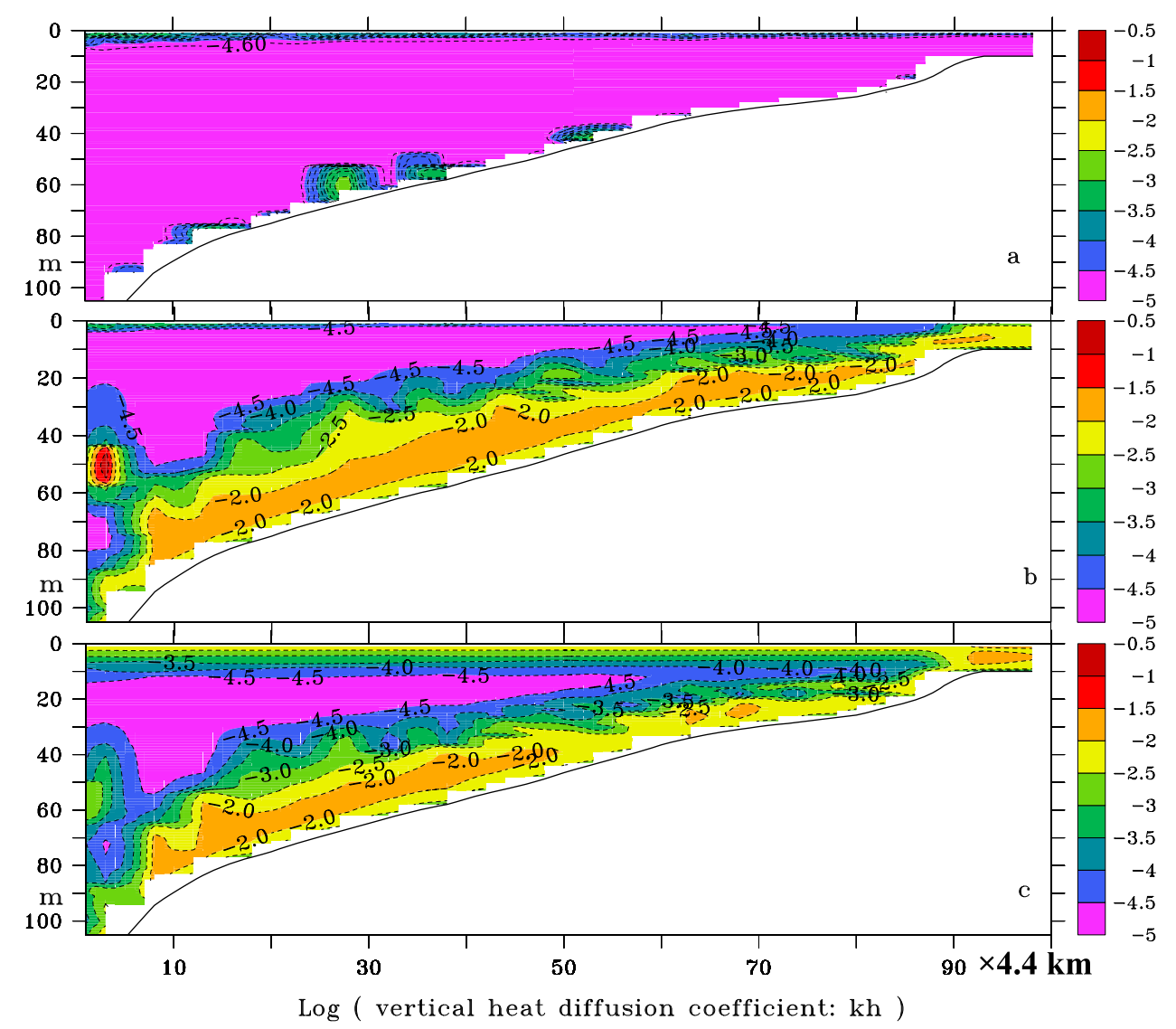

Figure 11. Model-simulated vertical heat diffusion coefficient $\log \left(K_{h}\right)\left(\mathrm{m}^{2} \mathrm{~s}^{-1}\right)$ along the same section as temperature in July. (a) Case 1: circulation only. (b) Case 2: the circulation and tides are simulated simultaneously, and the mixing is strong in the bottom layer. (c) Case 3: when wave mixing is considered, the circulation and tidal current are simulated simultaneously; mixing becomes strong in both the upper and the bottom mixed layers.

\subsection{Model Application: The Cold Pool}

\subsubsection{Observations}

[43] A distinct feature on the Bering Shelf is the cold water (cold pool) near the bottom in the middle shelf (50-100 $\mathrm{m}$ isobaths) that persists throughout the summer [Takenouti and Ohtani, 1974; Kinder and Schumacher, 1981b; Wyllie-Echeverria, 1995]. The cold water was even observed in late September and early October [Kinder and Schumacher, 1981b]. The largest vertical temperature difference, surface minus bottom, is $>7^{\circ} \mathrm{C}$ in the middle domain, suggesting that the cold pool survives the summer. The cold pool extends from the Gulf of Anadyr in the west with a temperature of $<-1.0^{\circ} \mathrm{C}$ [Hufford and Husby, 1972] to a variable eastern boundary over the southeastern shelf with temperature of $2^{\circ} \mathrm{C}$ [Maeda et al., 1967]. The size of the cold pool varies on the basis of the past winter's meteorological conditions. The minimum annual extent can reach eastward about $170^{\circ} \mathrm{W}$, while the maximum extent can cover Bristol Bay (Figure 12f).

[44] The existence of the cold pool in summer is important not only to the physical environment, but also to marine ecosystems. The cold pool is an ideal habitat to some arctic cold water species such as arctic cod, and acts as a barrier to certain species such as walleye pollock since they prefer water temperature warmer than $2^{\circ} \mathrm{C}$. When the volume and extent of the cold pool change, the population of local species may increase or decrease accordingly to their preference. Thus, the cold pool can affect biomass growth rate and distributions on the Bering Sea shelf.

\subsubsection{Simulation Results}

[45] The summer (August-averaged) cold pool is reproduced by the model with both tidal and wave mixing (Figure 13), which compares very well qualitatively to the observed extent (Figure 12f). The cold water lies on the middle shelf between the 50 and $100 \mathrm{~m}$ isobaths. The bottom temperature increases gradually from the $50 \mathrm{~m}$ isobath to the Alaskan coast. The maximum temperature reaches $11^{\circ} \mathrm{C}$ near the Norton Sound coast. The basin water at $200 \mathrm{~m}$ is mainly the slope water of $>3^{\circ} \mathrm{C}$. The minimum bottom temperature in the middle of the southeastern shelf is $>0^{\circ} \mathrm{C}$, compared to the northwestern shelf bottom water of $<0^{\circ} \mathrm{C}$.

[46] Sea surface temperature on the Bering Shelf starts to rise at the end of May or at the beginning of June after the melting of sea ice. From June to August, the temperature of the whole water column begins to increases gradually, while the surface temperature increases faster than the bottom layer. Thus, the maximum temperature difference between surface and bottom increases gradually: $>3^{\circ} \mathrm{C}$ in June (Figure 12a), $>6^{\circ} \mathrm{C}$ in July (Figure 12b), and $>7^{\circ} \mathrm{C}$ in August (Figure 12c). The difference reduces to $>6^{\circ} \mathrm{C}$ in September (Figure 12d) 

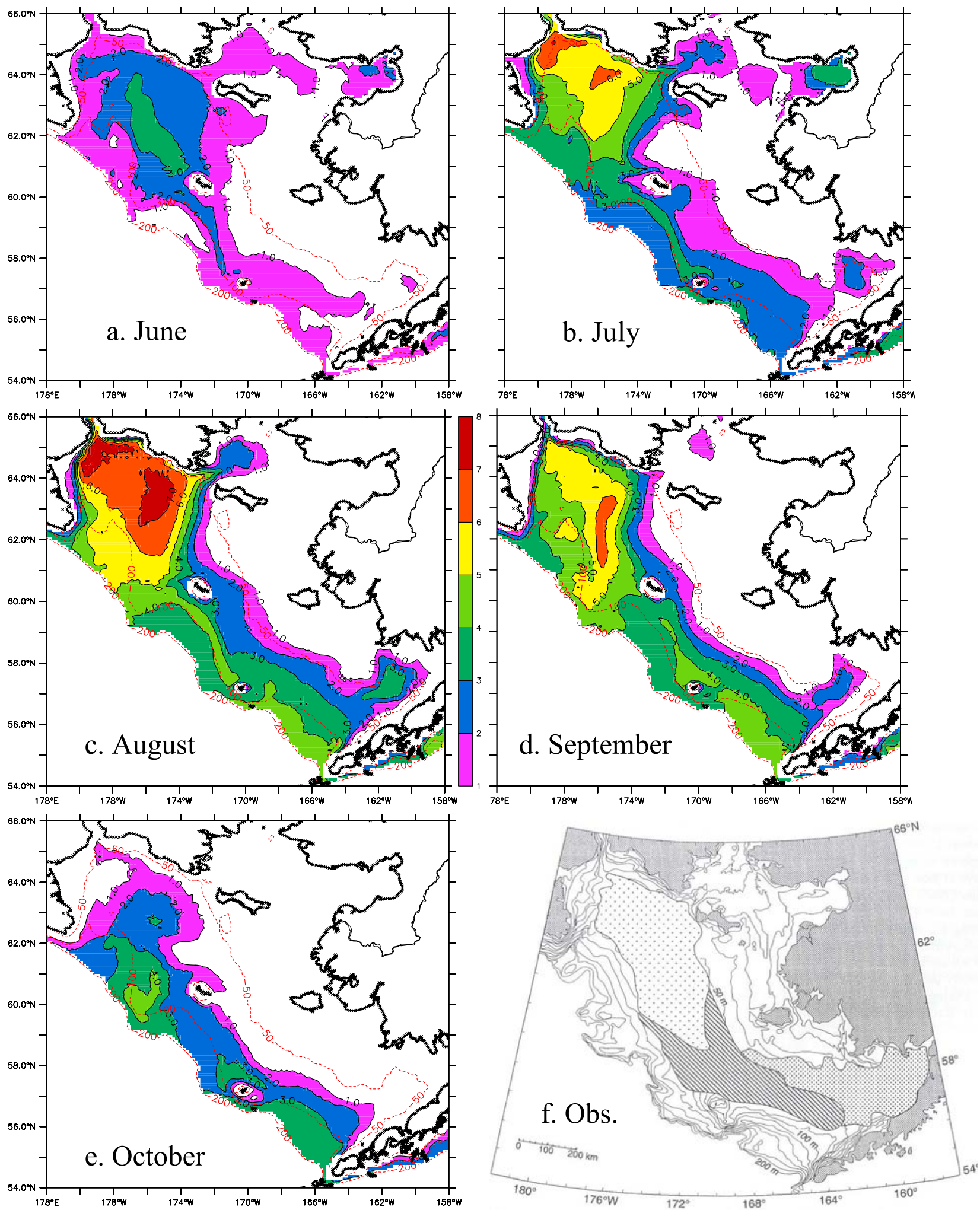

Figure 12. Model-simulated temperature difference between the upper and bottom layers (surface minus bottom) on the Bering Sea shelf $(<200 \mathrm{~m})$ in the control run in (a) June, (b) July, (c) August, (d) September, and (e) October. The blank region $(<200 \mathrm{~m})$ indicates that the difference is less than $1{ }^{\circ} \mathrm{C}$. The dashed lines indicate 50,100, and $200 \mathrm{~m}$ isobaths. (f) Changes in the extent of the cold pool over the eastern Bering Sea Shelf. Shown are the minimum annual extent that occurs eastward to about $170^{\circ} \mathrm{W}$ (light stippling), the 21-year average extent (eastward to about $163^{\circ} \mathrm{W}$; light stippling plus stripes), and the maximum extent that continues eastward and covers Bristol Bay (reproduced from Wyllie-Echeverria [1995]). 


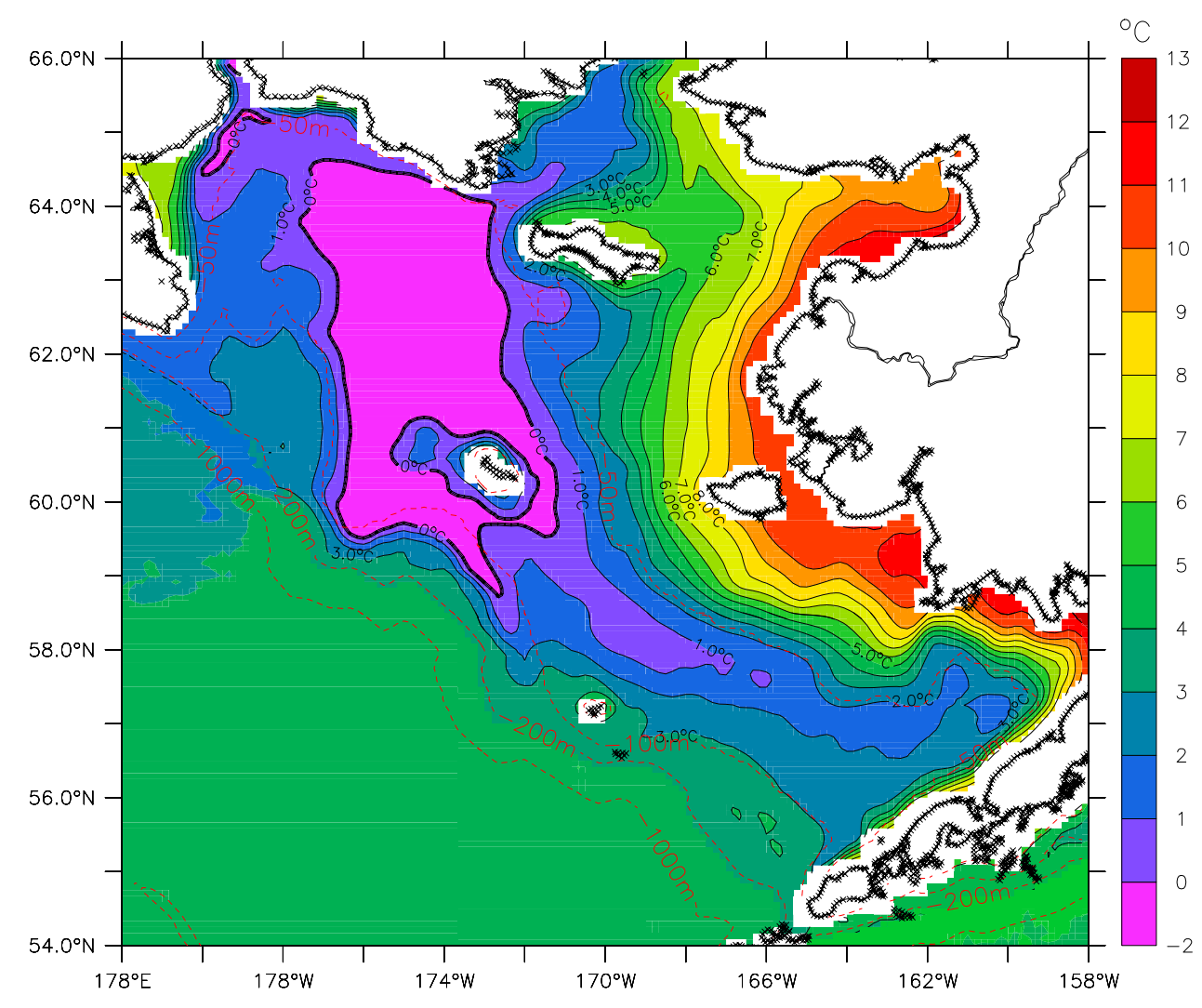

Figure 13. Model-simulated, August-averaged bottom temperature with tidal and wave mixing (note that the temperature at $200 \mathrm{~m}$ is used if the topography is deeper than $200 \mathrm{~m}$ ). The cold pool appears between 50 and $100 \mathrm{~m}$ isobaths compared to the warm Alaskan coastal water and the deep basin water.

when the surface cooling occurs, and it continuously decreases to $>4^{\circ} \mathrm{C}$ in October (Figure 12e) because the surface cooling is the dominant process. The water column becomes vertically homogenous from November to next May (not shown).

\subsubsection{Formation of the Cold Pool}

[47] A vertically stable temperature structure is a major factor that insulates heat transfer from the surface layer to the bottom. From December to the next April (not shown), the shelf water temperature is vertically homogenous because of strong vertical mixing. In May, solar radiation increases, so does the temperature on the southeastern shelf (Figure 14a), while the northwestern shelf is still cold during ice melting. The temperature in the whole domain continuously increases in June (Figure 14b), and the temperature in the northwestern shelf increases to $>0^{\circ} \mathrm{C}$. An interesting feature is that the isotherms tilt upward from southeastward to northwestward along the section, which is due to the persistence of ice cover in the north and is also due to northward heat transport by the northwestward shelf current (see Figure 15b). This feature is even more distinct in July and August (Figures 14c and 14d). The upper mixed layer of $20 \mathrm{~m}$ shows up in August (Figure 14d), and the cold water remains below $20 \mathrm{~m}$. The upper mixed layer deepens to $30 \mathrm{~m}$ in September (Figure 14e) and to $50 \mathrm{~m}$ in October (Figure 14f). There are two cold water centers with a dome shape in July, August, and September, which are separated by the shallow bathymetry close to section A (see Figure 1).
[48] Sea surface temperature increases gradually from late May to August, forming the vertically stable structure. The stable water column, in return, is unfavorable for transferring heat from the surface to the bottom, which, a positive feedback process, helps to maintain the vertical stability. The volume of the cold pool decreases gradually from June to September because of continuous solar heating, diffusion, and lateral advection. Nevertheless it survives the summer all the way to October. The shelf water is mixed to be almost vertically homogenous in November (Figure 14g) owing to surface cooling and dynamic vertical mixing caused by both tides and waves. From November on, the new cold bottom water $\left(<0^{\circ} \mathrm{C}\right)$ in the western shelf starts to form owing to the surface cooling.

[49] The lateral mixing between the cold pool and horizontal water transport to the middle shelf is limited (Figure 15a), because the summer (June-August vertically averaged) subtidal current on the Bering shelf (Figure 15b) is relatively weak $(<5 \mathrm{~cm} / \mathrm{s})$, and flows northwestward or northward. The warm water that enters from the Unimak Pass (about 3-4 cm/s) flows northeastward along the Alaska Peninsula into Bristol Bay, then flows anticlockwise along the $40-50 \mathrm{~m}$ isobaths and exits the bay (at about $2-3 \mathrm{~cm} / \mathrm{s}$ ). The subtidal currents between the 100 and $200 \mathrm{~m}$ isobaths $(1-2 \mathrm{~cm} / \mathrm{s})$ are even weaker, compared to the middle shelf current. This indicates small mixing (or entrainment or exchange) between the basin water and the shelf water owing to shelf-break fronts [Kinder and Coachman, 1978]. The 


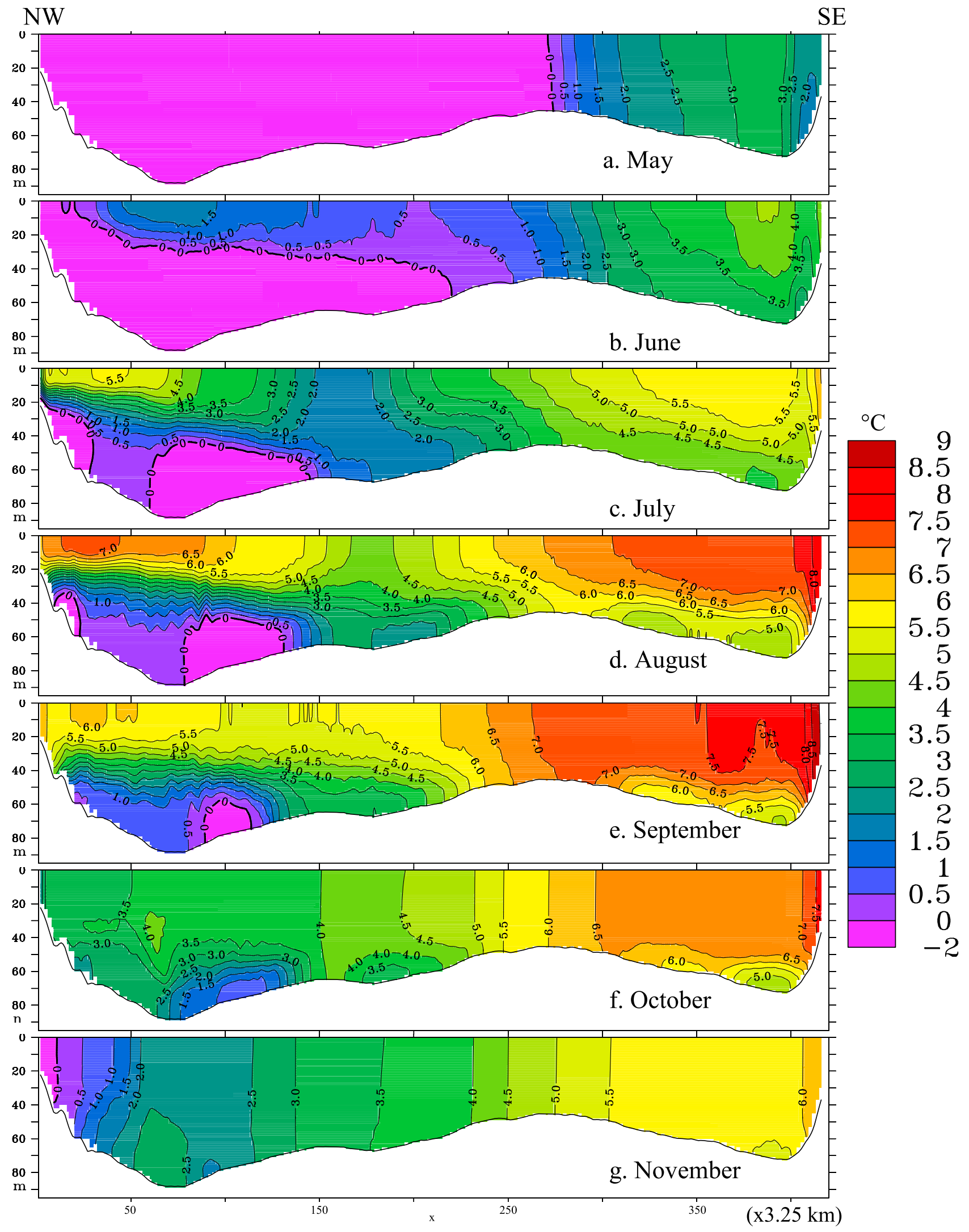

Figure 14. Model-simulated monthly temperature along transect B (see Figure 1 for the location) with tidal and wave mixing. The generation and maintenance of the cold pool is clearly shown. 

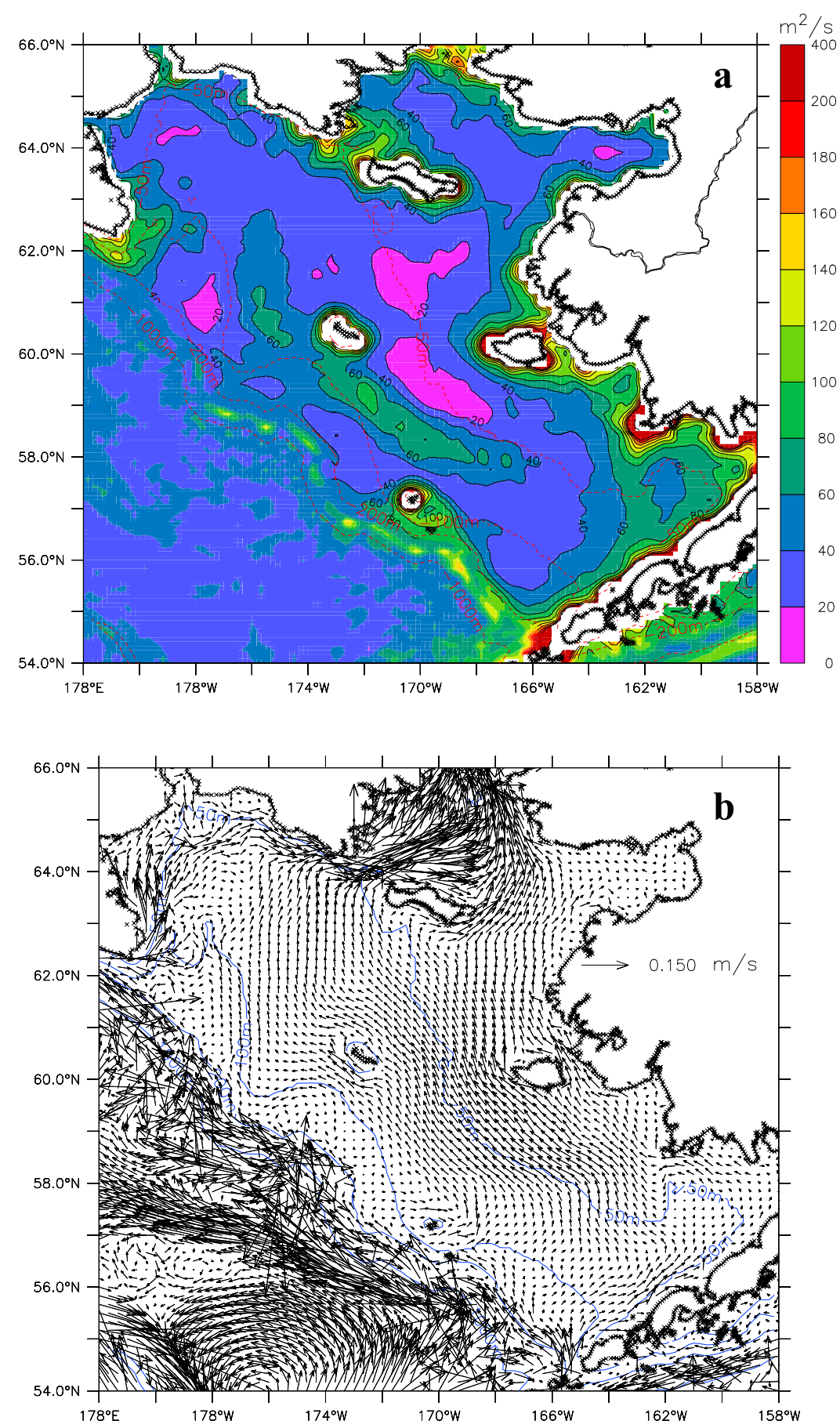

Figure 15. Model-simulated (a) horizontal mixing coefficient with tidal and wave mixing and (b) tidalfiltered subtidal current in summer (June-August vertically averaged). The vectors are drawn every two grids in both longitude and latitude. Isobaths of 50, 100, and $200 \mathrm{~m}$ are also shown.

warm basin water is hardly advected to the shallow middle shelf during summer where the cold pool is entrenched also due to the outer front [Kinder and Schumacher, 1981a, 1981b; Belkin and Cornillon, 2005] and due to a summer downwelling along the BSC. The northward or northwestward currents hardly mix the surface warm water from the Alaskan coast with the cold pool in the bottom of the middle shelf (Figure 15a). The narrow warm Anadyr Current that flows along $(<50 \mathrm{~m}$ isobath) the eastern Siberian coast contributes limited heat to the middle shelf, which, on the contrary, entrains the cold water and cools down north of St. Lawrence Island. The horizontal mixing (Figure 15a) is strong along the coastal region, around islands, and the Aleutian Islands mainly owing to tidal mixing, while on the mid shelf where the cold pool occupies, the mixing coefficient is small. This is why the lateral/horizontal mixing is limited, so that the cold pool is insulated in the mid shelf, in addition to the vertical insulation by strong subsurface thermocline formed by wave mixing (not shown), as discussed in section 3.3 . 


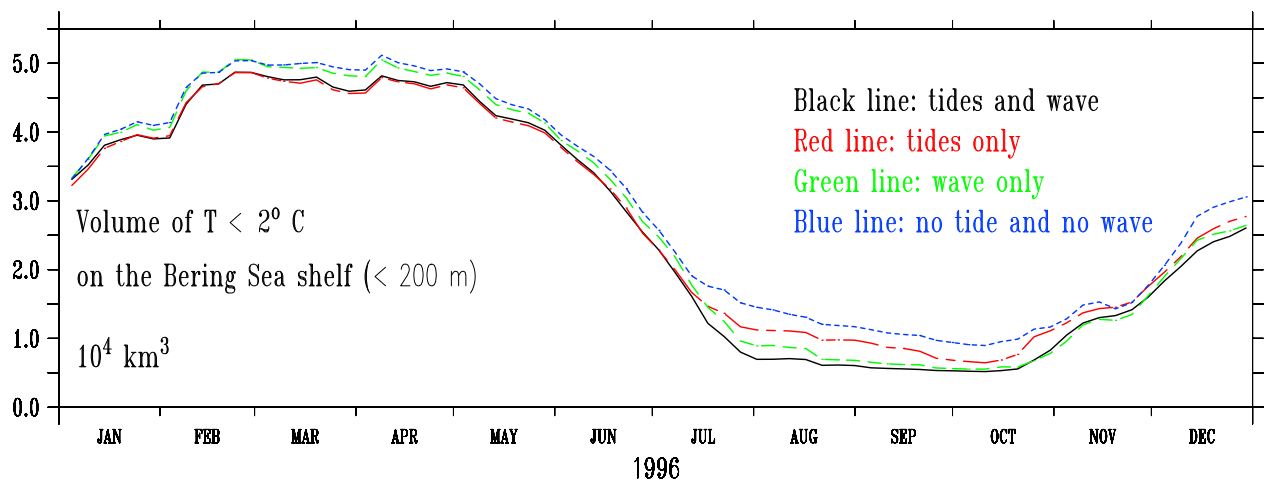

Figure 16. Model-simulated seasonal cycles of the volume of the cold pool with both tidal and wave mixing (control run, solid black line), tidal mixing only (case 1, dot-dashed red line), wave mixing only (case 2, dashed green line), and neither tidal nor wave mixing (case 3, dotted blue line). Units are $10^{4} \mathrm{~km}^{3}$.

[50] Therefore, with the vertical insulation by stable temperature structure and without the effective horizontal heat transport from basin and inner shelf to the middle shelf, the cold winter water is preserved in the middle shelf for the whole summer, until the surface cooling occurs, which destabilizes the water column in autumn. In winter, the surface water can be mixed all the way down to the bottom, forming the new winter bottom water that is the origin of the summer cold pool.

\subsubsection{Volume of the Cold Pool and Its Sensitivity to Tidal and Wave Mixing}

[51] To examine the seasonal cycle of the cold pool's extent, the volume of the cold pool is defined as

$$
\text { Volume }_{-C P}(t)=\sum_{i, j, k=1}^{N, M, K} \Delta x_{i, j, k} \Delta y_{i, j, k} \Delta z_{i, j, k} \text {, if } \mathrm{T}(x, y, z, t) \leq 2{ }^{\circ} \mathrm{C}
$$

The seasonal cycle of the volume of the cold pool with the tidal and wave mixing was calculated (Figure 16, solid black line). The maximum volume is $4.87 \times 10^{4} \mathrm{~km}^{3}$ in February-March, whereas the minimum volume is about $0.51 \times 10^{4} \mathrm{~km}^{3}$ in October (see Table 3 for the control run). The minimum volume is about one order of magnitude smaller than the maximum. The seasonal variation of the extent or volume of the cold pool determines the seasonal variations of habitat and distribution of biomass.

[52] As discussed in section 3.3, tidal and wind-wave stirring significantly deepen the surface and bottom mixedlayer depth by mixing. Thus, these two factors are hypothesized to affect the volume of the cold pool. Thus, we conducted three additional experiments with: (1) tidal mixing only, (2) wave mixing only, and (3) no tidal and no wave mixing. With the same initial conditions, the model was run for a complete seasonal cycle in each case. Then, the volume of the cold pool was tracked using the definition above. Table 3 shows the statistics of the volume variation. The mean volume for the control run is the smallest owing to tidal and wave mixing, while the mean volume for case 3 is the largest owing to a lack of both tidal and wave mixing. The volume with tidal mixing is comparable to that with wave mixing, indicating both have a comparable impact on the cold pool. The minimum volume occurs in October with tidal and wave mixing $(0.51)$; however, without this mixing, the minimum volume of 0.95 in case 3 is about two times larger than the control run. From Table 3, the minimum volume owing to wave mixing is smaller than that owing to tidal mixing. This indicates that in summer to autumn, wave mixing is more important in entraining the cold pool by mixing the warm upper layer water, while tides mainly mix the edge of the cold pool with the bottom ambient water. The physical explanation is that because the vertical temperature gradient in the upper layer is large in summer, wave mixing is more effective than the tidal mixing in reducing the vertical temperature gradient, and thus the volume of the cold pool.

[53] The maximum volume in winter measures the production of the shelf winter water. From Table 3, the control run has the smallest maximum volume in winter owing to vigorous mixing by tides and waves, compared to case 3 without mixing, with a $5 \%$ difference. There is a $3 \%$ difference between the tidal mixing case and the wave mixing case, indicating tidal mixing is more important than wave mixing in the winter water mass production on the Bering Shelf. The reason is that tidal mixing effectively works on vertically well-mixed water column, compared to the summer stratified water column. Therefore, processes of both tidal and wave mixing should be included in the coastal ocean models to accurately simulate winter and summer water masses and their thermohaline structures.

\section{Conclusions and Summary}

[54] On the basis of the above investigations, the following conclusions can be drawn:

Table 3. Cold Pool Volume Statistics in the Control Run in Comparison With Three Scenarios Over a Seasonal Cycle

\begin{tabular}{lccc}
\hline \multicolumn{1}{c}{ Experiment } & Mean $\left(10^{4} \mathrm{~km}^{3}\right)$ & Standard Deviation $\left(10^{4} \mathrm{~km}^{3}\right)$ & Maximum $\left(10^{4} \mathrm{~km}^{3}\right)$ \\
\hline Control run: tidal and wave & 2.65 & 1.67 & 4.87 \\
Case 1: tidal only & 2.75 & 1.54 & 4.88 \\
Case 2: wave only & 2.76 & 1.71 & 0.51 \\
Case 3: no tidal and no wave & 2.97 & 1.56 & 0.64 \\
\hline
\end{tabular}




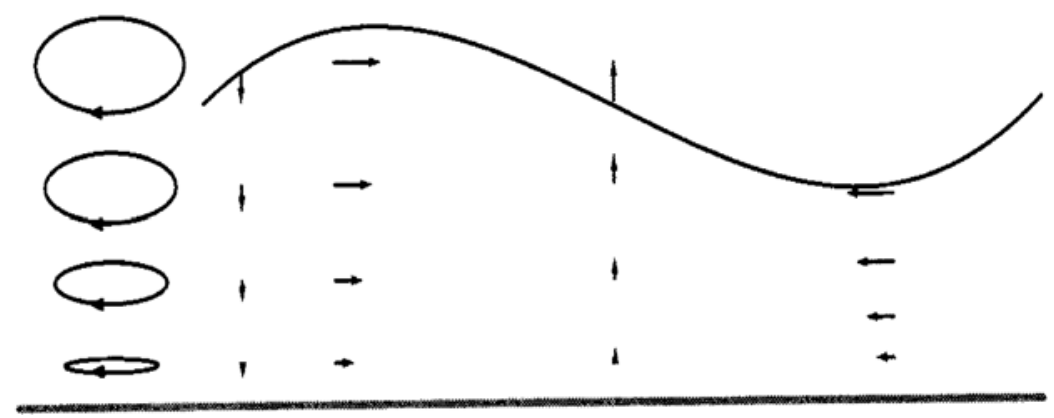

Figure A1. Schematic diagram of displacement of water particles in an ocean wave.

[55] 1. The 3-D Bering Sea basin-scale CIOM reproduces qualitatively observed ocean circulation pattern. The circulation in the deep basin is cyclonic with little seasonal change, while the shelf current varies owing to opposite wind stress patterns between winter and summer. The Bering shelf currents in summer are weak and northward or northeastward. The Gulf of Anadyr Current is stronger in summer than in winter during which the reversal (southward) flow occurs. The major current transports compare reasonably to the observations. The simulated transports through the Aleutian passes also mimic many observed features in terms of magnitude and direction.

[56] 2. Using the newly introduced parameterized windwave mixing along with tidal mixing, the shelf thermohaline structures, in particular the upper mixed-layer and bottom mixed-layer depths, are well reproduced and compared favorably to the measurements. These are the major dynamical mechanisms forming the seasonal thermocline structure. The wave mixing parameterization overcomes the weakness of many existing models: the capability to correctly reproduce the upper mixed-layer depth in a strongly stratified upper ocean in summer. The advantage of this parameterization is that it is practical in a numerical model without involving running a sophisticated wave model [Qiao et al., 2004]. This parameterization is again successfully applied in this study after it was applied to the East China Sea [Hu et al., 2004].

[57] 3. The clockwise subtidal currents/eddies reproduced by the model around the Pribilof Islands is confirmed to be rectified by tidal currents, indicating that tidal residual currents induced by the nonlinear effect should not be ignored. Thus, in the Bering Sea, the ocean circulation and tides should be simulated simultaneously, because of the complicated topographic features ranging from deep basins to broad shelves and the Aleutian Islands where tidal currents dominate.

[58] 4. The cold pool was reproduced on the Bering Sea Shelf. The winter cold water is preserved in the middle shelf throughout the summer owing to vertical insulation from the stable stratified temperature structure and also owing to the lack of effective horizontal heat transport from the deep basin and the inner shelf. Tidal and wave mixings are the key factors that accurately produce the cold pool water masses, although tidal mixing is more effective in winter, while wave mixing is more effective in summer.

\section{Appendix A: Derivation of the Wind-Wave Mixing Parameterization}

[59] Total vertical viscosity is assumed to be a linear addition of $K_{m}$ and $K_{m w}: \mathrm{K}_{m}^{\prime}=K_{m}+K_{m w}$ (a similar formula is applied to total vertical diffusivity coefficient), where $K_{m}$ is calculated from the level 2.5 turbulence closure model [Mellor and Yamada, 1982] and $K_{m w}$ is the mixing coefficient owing to wind waves, as discussed below.

[60] Ocean surface wave motion plays an important role in generating ocean turbulence. There are three mechanisms for waves to produce surface turbulence: (1) Stokes' drift [Phillips, 1977, section 3.3], (2) imperfectly irrotational wave movement generates Reynolds stress on the mean flow [Phillips, 1977, section 3.4; Cheung and Street, 1988, case II], and (3) wave breaking can release turbulent kinetic energy that is available to be mixed down into surface layer [Kitaigorodskii et al., 1983; Thorpe, 1984, 1993; Craig and Banner, 1994]. Because the wave movement is not perfectly irrotational, it can generate Reynolds stress on the mean flow [Phillips, 1977] if there is instability in a shear flow. Water particles with a wave oscillate around their ellipses at different speeds (see Figure A1), which leads to vertical shear. Vertical shear instability then results in ocean turbulence. The higher the wind speed, the higher the waves, and the stronger the turbulence. Therefore, the contribution of surface waves to turbulence results from vertical shear of oscillating horizontal wave velocity.

[61] Similar to Qiao et al. [2004], current velocity, temperature, and salinity can be decomposed to a mean and perturbation:

$$
U_{i}=\overline{U_{i}}+u_{i}, T=\bar{T}+\theta, S=\bar{S}+s,
$$

where the bar represents the mean, while others represent the perturbation. The subscript $\mathrm{i}(=1,2,3)$ denotes the Cartesian coordinate $(\mathrm{x}, \mathrm{y}, \mathrm{z})$. The velocity perturbation consists of current-induced turbulence $u_{i c}$ and wave-induced turbulence $u_{i w}$; that is, $\mathrm{u}_{i}=\mathrm{u}_{i c}+\mathrm{u}_{i w}$. Thus, the Reynolds stress can be written as

$$
-\overline{u_{i} u_{j}}=-\overline{u_{i w} u_{j w}}-\overline{u_{i w} u_{j c}}-\overline{u_{i c} u_{j w}}-\overline{u_{i c} u_{j c}},
$$

where the first term on the right hand side is the waveinduced Reynolds stress, and the fourth term is the currentinduced turbulence, or kinematic viscosity, which can be calculated using the 2.5-level turbulence closure model of Mellor and Yamada [1982]. Similarly, Reynolds diffusivity for temperature and salinity can be expressed as

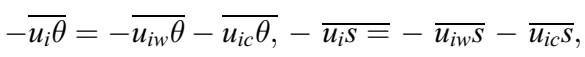

where similarly the first and second terms represent waveand current-induced diffusivity, respectively. It is seen that 
the Mellor-Yamada turbulence closure scheme does not include wave-induced mixing, which is a periodic, mechanical mixing since surface waves are driven by winds anywhere at sea. The second and third terms are the mixing owing to interactions between waves and currents, which is beyond the scope of this paper.

[62] Following the Prandtl theory [Fang and Ichiye, 1983], wave-induced Reynolds stress can be expressed as

$$
-\overline{u_{1 w} u_{3 w}}=K_{m w} \frac{\partial \overline{U_{1}}}{\partial z}
$$

where

$$
K_{m w}=l^{2} \frac{\partial \overline{U_{1 w}}}{\partial z}
$$

where $K_{m w}$ is the vertical turbulence eddy coefficient, $l$ is the mixing length of wave-induced turbulence, which is proportional to the vertical displacement of water particles. $U_{1 w}$ is wave-associated water particle velocity in the horizontal direction. Next, we will derive the expression of $\overline{U_{1 w}}$.

[63] Water particles oscillate around their ellipses (Figure A1) as a wave propagates. In deep water (when $k d \gg 1$, short wave), the fluid particle displaces along the ellipses around position $(x, 0, z)$, then [Phillips, 1977]:

$$
U_{1 w}=a \omega e^{k z} \cos (k x-\omega t),
$$

where $a$ is the wave amplitude, $\omega$ is the wave circular frequency $(=2 \pi / T), t$ is the time, $\lambda$ is the wavelength $(=2 \pi / k)$, $k$ is the wave number, and $d$ is the water depth.

[64] The mean speed (not velocity) of a water particle at position $(0,0, z)$ in a period $T$ is

$$
\overline{U_{1 w}}=\frac{4}{T} \int_{0}^{\frac{T}{4}} U_{1 w} d t=\frac{4 a}{T} e^{\frac{2 \pi z}{\lambda}} .
$$

We use the von Kármán mixing length parameterization [Chen and Jaw, 1997],

$$
l=\nu \frac{\partial \overline{U_{1 w}}}{\partial z} / \frac{\partial^{2} \overline{U_{1 w}}}{\partial z^{2}},
$$

where $\nu$ is the von Kármán constant.

[65] Substituting (A6) into (A7) yields

$$
l=\frac{\nu \lambda}{2 \pi} \text {. }
$$

Substituting (A6) and (A8) into (A4) yields

$$
K_{m w}=\frac{2 a \nu^{2} \lambda}{\pi T} e^{\frac{2 \pi z}{\lambda}}
$$

The unknown variables are wavelength $\lambda$, wave period $T$, and wave amplitude $a$. We now parameterize their relationships to wind speed.

[66] Wave propagation phase speed is defined as

$$
c=\frac{\omega}{k}=\frac{\lambda}{T}=\beta W, \text { or } T=\lambda / \beta W,
$$

where the wave speed is assumed to be proportional to $\beta W, W$ is the wind speed, $\beta$ is the wave age, $0<\beta<1$ for a growing wave, $\beta=1$ for a mature wave. As wind increases, a wave increases in height and in wavelength and reaches an energy balance. Then the wave decreases or dissipates [Williams, 1968].

[67] In deep water [Gill, 1982, p.106, equation 5.5.1], since $\omega^{2}=g k, c=\omega / k$, so $c^{2}=g \lambda / 2 \pi$,

$$
\lambda=\frac{2 \pi c^{2}}{g} .
$$

Substituting (A10) into (A11) gives

$$
\lambda=\frac{2 \pi \beta^{2} W^{2}}{g} .
$$

Wave amplitude is defined as [Williams, 1968, pp. 162 and 171]

$$
a=\frac{\lambda \delta}{2}
$$

where $\delta$ is the empirical parameter of wave steepness (or slope). Theoretically, a wave cannot attain a steepness greater than 0.14 while remaining stable. When $\delta$ reaches 0.14 , a wave starts to break [Williams, 1968].

[68] Substituting (A12) into (A13) then

$$
a=\frac{\pi \delta \beta^{2} W^{2}}{g} .
$$

Substituting $\lambda$ (from (A12)), $T$ (= $\lambda / \beta W$, from (A10)), and $a$ (from (A14)) into (A9) yield

$$
K_{m w}=\frac{2 \nu^{2}}{g} \delta \beta^{3} W^{3} e^{\frac{g z}{\beta^{2} W^{2}}}
$$

where $K_{m w}$ is the wave-induced mixing coefficient; $\beta$ is the wave age $(0<\beta<1$ for growing wave, and $\beta=1$ for mature wave), $\delta$ is the wave steepness ( $\delta=2 a / \lambda, a$ is the amplitude and $\lambda$ is the wavelength), $W$ is the wind speed, $z<0$ is the depth, $\nu=0.4$ is the von Kármán constant, and $\mathrm{g}$ is the acceleration of gravity.

[69] Acknowledgments. Thanks for support from IARC/JAMSTEC Cooperative Agreement, University of Alaska Costal Marine Institute and Minerals Management Service, and the NOAA Russian-American LongTerm Census of the Arctic (RUSALCA) International Polar Year (IPY) modeling project awarded to J.W. We would like to thank Cathy Darnell and David Schwab for editing a draft of the paper. We also credit the use of measurement illustrations to P. Stabeno and J. Overland of NOAA PMEL, published by the Alaska Sea Grant College Program, and to T. WyllieEcheverria, published in her Ph.D. thesis by the Institute of Marine Science, University of Alaska Fairbanks. This is GLERL contribution 1537.

\section{References}

Belkin, I. M., and P. C. Cornillon (2005), Bering Sea thermal fronts from Pathfinder data: Seasonal and interannual variability, Pac. Oceanogr., 3, $6-20$.

Blumberg, A. F., and G. L. Mellor (1987), A description of a threedimensional coastal ocean circulation model, in Three-Dimensional 
Coastal Ocean Models, Coastal Estuarine Sci., vol. 4, edited by N. S. Heaps, pp. 1-16, AGU, Washington, D. C.

Chen, C. J., and S. Y. Jaw (1997), Fundamentals of Turbulence Modelling 292 pp., Taylor \& Francis, Philadelphia, $\mathrm{Pa}$.

Cheung, T. K., and R. L. Street (1988), The turbulent layer in water at an air-water interface, J. Fluid Mech., 194, 133-151, doi:10.1017/ S0022112088002927.

Clement, J. L., W. Maslowski, L. W. Cooper, J. M. Grebmeier, and W. Walczowski (2005), Ocean circulation and exchanges through the northern Bering Sea: 1979-2001, Deep Sea Res., Part II, 52, 3509-3540, doi:10.1016/j.dsr2.2005.09.010.

Coachman, L. K. (1993), On the flow field in the Chirikov Basin, Cont. Shelf Res., 13, 481-508, doi:10.1016/0278-4343(93)90092-C.

Coachman, L. K., and K. Aagaard (1981), Reevaluation of water transports in the vicinity of Bering Strait, in The Eastern Bering Sea Shelf: Oceanography and Resources, vol. 1, edited by D. W. Hood and J. A. Calder, pp. 95-110, Off. of Mar. Pollut. Assess., Univ. of Wash. Press, Seattle.

Coachman, L. K., and K. Aagaard (1988), Transports through Bering Strait: Annual and interannual variability, J. Geophys. Res., 93, 15,535-15,539, doi:10.1029/JC093iC12p15535.

Coachman, L. K., K. Aagaard, and R. B. Tripp (1975), Bering Strait: The Regional Physical Oceanography, 172 pp., Univ. of Wash. Press, Seattle, Wash.

Cokelet, E. D., M. L. Schall, and D. M. Dougherty (1996), ADCP-referenced geotropic circulation in the Bering Sea basin, J. Phys. Oceanogr., 26 1113-1128, doi:10.1175/1520-0485(1996)026<1113:ARGCIT>2.0.CO;2.

Craig, P. D., and M. L. Banner (1994), Modeling wave-enhanced turbulence in the ocean surface layer, J. Phys. Oceanogr., 24, 2546-2559, doi:10.1175/1520-0485(1994)024<2546:MWETIT>2.0.CO;2.

Danielson, S., and Z. Kowalik (2005), Tidal currents in the St. Lawrence Island region, J. Geophys. Res., 110, C10004, doi:10.1029/ 2004JC002463.

Ezer, T., and G. L. Mellor (1997), Simulations of the Atlantic Ocean with a free surface sigma coordinate ocean model, J. Geophys. Res., 102, $15,647-15,657$.

Ezer, T., H. Arango, and A. F. Shchepetkin (2002), Developments in terrainfollowing ocean models: Intercomparisons of numerical aspects, Ocean Modell., 4, 249-267, doi:10.1016/S1463-5003(02)00003-3.

Fang, G., and T. Ichiye (1983), On the vertical structure of tidal currents in a homogeneous sea, Geophys. J. R. Astron. Soc., 73, 65-82.

Favorite, F. (1974), Flow into the Bering Sea through Aleutian Island passes, in Oceanography of the Bering Sea: With Emphasis on Renewable Resources, edited by D. W. Hood and E. J. Kelley, pp. 3-37, Inst. of Mar. Sci., Univ. of Alaska, Fairbanks.

Gill, A. E. (1982), Atmosphere-Ocean Dynamics, Int. Geophys. Ser., vol. 30, 662 pp., Elsevier, New York.

Hermann, A. J., P. J. Stabeno, D. B. Haidvogel, and D. L. Musgrave (2002), A regional tidal/subtidal circulation model of the southeastern Bering Sea: Development, sensitivity analyses and hindcasting, Deep Sea Res., Part II, 49, 5945-5967, doi:10.1016/S0967-0645(02)00328-4.

Hibler, W. D., III (1979), A dynamic and thermodynamic sea ice model, J. Phys. Oceanogr., 9, 815-846, doi:10.1175/1520-0485(1979) 009<0815:ADTSIM>2.0.CO;2.

Hibler, W. D., III (1980), Modeling a variable thickness sea ice cover, Mon. Weather Rev., 108, 1943-1973, doi:10.1175/1520-0493(1980) 108<1943:MAVTSI $>2.0 . \mathrm{CO} ; 2$.

$\mathrm{Hu}, \mathrm{H}$. , and J. Wang (2008), Modeling the ocean circulation in the Bering Sea, Chin. J. Polar Sci., 19, 193-211.

Hu, H., Y. Yuan, and Z. Wan (2004), Study on hydrodynamics of the Bohai Sea, the Yellow Sea and the East China Sea with wave-current coupled numerical model (in Chinese with English abstract), Acta Oceanol. Sin., 4, $19-32$.

Hufford, G. L., and D. M. Husby (1972), Oceanographic survey of the Gulf of Anadyr August 1970, Oceanogr. Rep. CG-373-52, U.S. Coast Guard, Washington, D. C.

Johnson, G. C., P. J. Stabeno, and S. C. Riser (2004), The Bering Slope Current System revisited, J. Phys. Oceanogr., 34, 384-398, doi:10.1175/ 1520-0485(2004)034<0384:TBSCSR $>2.0$. CO;2.

Kachel, N. B., G. L. Hunt, S. A. Salo, J. D. Schumacher, P. J. Stabeno, and T. Whitledge (2002), Characteristics and variability of the inner front of the southeastern Bering Sea, Deep Sea Res., Part II, 49, 5889-5909, doi:10.1016/S0967-0645(02)00324-7.

Kinder, T. H., and L. K. Coachman (1978), The front overlaying the continental slope in the eastern Bering Sea, J. Geophys. Res., 83, 4551-4559, doi:10.1029/JC083iC09p04551.

Kinder, T. H., and J. D. Schumacher (1981a), Hydrographic structure over the continental shelf of the southeastern Bering Sea, in The Eastern Bering Sea Shelf: Oceanography and Resources, vol. 1, edited by D. W. Hood and J. A. Calder, pp. 31-52, Off. of Mar. Pollut. Assess., Univ. of Wash. Press, Seattle.
Kinder, T. H., and J. D. Schumacher (1981b), Circulation over the continental shelf of the southeastern Bering Sea, in The Eastern Bering Sea Shelf: Oceanography and Resources, vol. 1, edited by D. W. Hood and J. A. Calder, pp. 53-76, Off. of Mar. Pollut. Assess., Univ. of Wash. Press, Seattle.

Kitaigorodskii, S. A., M. A. Donelan, J. L. Lumley, and E. A. Terray (1983), Wave turbulence interactions in the upper ocean. part II: Statistical characteristics of wave and turbulent components of the random velocity field in the marine surface layer, J. Phys. Oceanogr., 13, 1988-1999, doi:10.1175/1520-0485(1983)013<1988:WTIITU>2.0.CO;2.

Kowalik, Z. (1999), Bering sea tides, in Dynamics of the Bering Sea, edited by T. R. Loughlin and K. Ohtani, pp. 93-127, Univ. of Alaska Sea Grant, Fairbanks.

Kowalik, Z., and P. Stabeno (1999), Trapped motion around the Pribilof Islands in the Bering Sea, J. Geophys. Res., 104, 25,667-25,684, doi:10.1029/1999JC900209.

Ladd, C., and N. A. Bond (2002), Evaluation of NCEP/NCAR reanalysis in the NE Pacific and the Bering Sea, J. Geophys. Res., 107(C10), 3158, doi:10.1029/2001JC001157.

Lefevre, F., F. H. Lyard, C. Le Provost, and E. J. O. Schrama (2002), FES99: A global tide finite element solution assimilating tide gauge and altimetric information, J. Atmos. Oceanic Technol., 19, 1345-1356, doi:10.1175/1520-0426(2002)019<1345:FAGTFE >2.0.CO;2.

Maeda, T., T. Fujii, and K. Masuda (1967), On the oceanographic condition and distribution of fish shoals in 1963. part 1. Studies on the trawl fishing grounds of the eastern Bering Sea (in Japanese), Bull. Jpn. Soc. Sci. Fish., $33,713-720$

Martin, P. J. (1985), Simulation of the mixed layer at OWS November and Papa with several models, J. Geophys. Res., 90, 903-916, doi:10.1029/ JC090iC01p00903.

Mellor, G. L. (2004), User's Guide for a Three-Dimensional, Primitive Equation, Numerical Ocean Model, 56 pp., Program in Atmos. and Oceanic Sci., Princeton Univ., Princeton, N. J.

Mellor, G. L., and A. F. Blumberg (2004), Wave breaking and ocean surface layer thermal response, J. Phys. Oceanogr., 34, 693-698, doi:10.1175/ 2517.1.

Mellor, G. L., and L. Kantha (1989), An ice-ocean coupled model, J. Geophys. Res., 94, 10,937-10,954, doi:10.1029/JC094iC08p10937.

Mellor, G. L., and T. Yamada (1982), Development of a turbulence closure model for geophysical fluid problems, Rev. Geophys., 20, 851-875, doi:10.1029/RG020i004p00851.

Mellor, G. L., T. Ezer, and L.-Y. Oey (1994), The pressure gradient conundrum of sigma coordinate ocean models, J. Atmos. Oceanic Technol., 11, 1126-1134, doi:10.1175/1520-0426(1994)011<1126: TPGCOS $>2.0 . \mathrm{CO} ; 2$.

Mizobata, K., J. Wang, and S. Saitoh (2006), Eddy-induced cross-slope exchange maintaining summer high productivity of the Bering Sea shelf break, J. Geophys. Res., 111, C10017, doi:10.1029/2005JC003335.

Mizobata, K., S.-I. Saitoh, and J. Wang (2008), Summer biological enhancement in relation to the mesoscale eddy at the shelf break in the vicinity of the Pribilof Islands, Deep Sea Res., Part II, 55, 1717-1728, doi:10.1016/ j.dsr2.2008.03.002.

Muench, R. D., J. D. Schumacher, and S. A. Salo (1988), Winter currents and hydrographic conditions on the northern central Bering Sea shelf, J. Geophys. Res., 93, 516-526, doi:10.1029/JC093iC01p00516.

National Oceanic and Atmospheric Administration (NOAA) (2001), Igitkin 1s. to Semisopochnoi Island, United States, Alaska-Aleutian Islands, 15th ed., Charts 16460, Washington, D. C.

National Oceanic and Atmospheric Administration (NOAA) (2003), Near Islands Buldir Island to Attu Island, United States, Alaska-Aleutian Islands, 10th ed., Charts 16420, Washington, D. C.

National Oceanic and Atmospheric Administration (NOAA) (2004a), Rat Islands Semisopochnoi Island to Buldir 1, United States, Alaska-Aleutian Islands, 14th ed., Charts 16440, Washington, D. C.

National Oceanic and Atmospheric Administration (NOAA) (2004b), Amkta Island to Igitkin Island; Finch Cove Seguam Island; Sviechnikof Harbor, Amilia Island, United States, Alaska-Aleutian Islands, 11th ed., Charts 16480, Washington, D. C.

National Oceanic and Atmospheric Administration (NOAA) (2004c) Unimak and Akutan Passes and approaches; Amak Island, United States, Alaska-Aleutian Islands, 22th ed., Charts 16520, Washington, D. C.

National Oceanic and Atmospheric Administration (NOAA) (2005), Unalaska 1. to Amukta 1., United States, Alaska-Aleutian Islands, 10th ed., Charts 16500, Washington, D. C

Ohshima, K. I., and S. Nihashi (2005), A simple ice-ocean coupled model for the Antarctic ice melt season, J. Phys. Oceanogr., 35, 188-201, doi:10.1175/JPO-2675.1.

Onishi, H., and K. Ohtani (1999), On seasonal and year to year variation in flow of the Alaskan Stream in the central north Pacific, J. Oceanogr., 55, 597-608, doi:10.1023/A:1007840802296. 
Overland, J. E., M. C. Spillane, H. Y. Hurlburt, and A. J. Wallcraft (1994), A numerical study of the circulation of the Bering Sea basin and exchange with the north Pacific Ocean, J. Phys. Oceanogr., 24, 736-758, doi:10.1175/1520-0485(1994)024<0736:ANSOTC $>2.0 . C O ; 2$

Overland, J. E., P. J. Stabeno, and S. Salo (1996), Direct evidence for northward flow on the northwestern Bering Sea shelf, J. Geophys. Res., 101, 8971-8976, doi:10.1029/96JC00205.

Overland, J. E., S. A. Salo, L. H. Kantha, and C. A. Clayson (1999), Thermal stratification and mixing on the Bering Sea shelf, in Dynamics of the Bering Sea, edited by T. R. Loughlin and K. Ohtani, pp. 129-146, Univ. of Alaska Sea Grant, Fairbanks.

Panteleev, G. G., P. Stabeno, V. A. Luchin, D. A. Nechaev, and M. Ikeda (2006), Summer transport estimates of the Kamchatka Current derived as a variational inverse of hydrophysical and surface drifter data, Geophys. Res. Lett., 33, L09609, doi:10.1029/2005GL024974.

Phillips, O. M. (1977), The Dynamics of the Upper Ocean, 2nd ed., 336 pp., Cambridge Univ. Press, New York.

Qiao, F., Y. Yuan, Y. Yang, Q. Zheng, C. Xia, and J. Ma (2004), Waveinduced mixing in the upper ocean: Distribution and application to a global ocean circulation model, Geophys. Res. Lett., 31, L11303, doi:10.1029/2004GL019824.

Reed, R. K., and P. J. Stabeno (1990), A year-long observation of water exchange between the North Pacific and the Bering Sea, Limnol. Oceanogr. 35, 1604-1609.

Reed, R. K., and P. J. Stabeno (1993), The recent return of the Alaskan Stream to Near Strait, J. Mar. Res., 51, 515-527, doi:10.1357/ 0022240933224025

Reed, R. K., and P. J. Stabeno (1994), Flow along and across the Aleutian Ridge, J. Mar. Res., 52, 639-648, doi:10.1357/0022240943076957.

Reed, R. K., and P. J. Stabeno (1997), Long-term measurement of flow near the Aleutian Islands, J. Mar. Res., 55, 565-575, doi:10.1357/ 0022240973224328

Reed, R. K., and P. J. Stabeno (1999a), The Aleutian North Slope Current, in Dynamics of the Bering Sea, edited by T. R. Loughlin and K. Ohtani, pp. 177-191, Univ. of Alaska Sea Grant, Fairbanks.

Reed, R. K., and P. J. Stabeno (1999b), A recent full-depth survey of Alaskan Stream, J. Oceanogr., 55, 79-85, doi:10.1023/ A:1007813206897.

Roach, A. T., K. Aagaard, C. H. Pease, S. A. Salo, T. Weingartner, V. Pavlov, and M. Kulakov (1995), Direct measurements of transport and water properties through the Bering Strait, J. Geophys. Res., 100, 18,443-18,457, doi:10.1029/95JC01673

Robinson, I. S. (1981), Tidal vorticity and residual circulation, Deep Sea Res., Part A, 28, 195-212, doi:10.1016/0198-0149(81)90062-5.

Schumacher, J. D., and P. J. Stabeno (1998), The continental shelf of the Bering Sea, in The Sea: The Global Coastal Ocean Regional Studies and Synthesis, vol. XI, edited by A. R. Robinson and K. H. Brink, pp. 869-909, John Wiley, Hoboken, N. J.

Schumacher, J. D., C. A. Pearson, and J. E. Overland (1982), On exchange of water between the Gulf of Alaska and the Bering Sea through Unimak Pass, J. Geophys. Res., 87, 5785-5795, doi:10.1029/JC087iC08p05785.

Smagorinsky, J. (1963), General circulation experiments with the primitive equations, I: The basic experiment, Mon. Weather Rev., 91, 99-164, doi:10.1175/1520-0493(1963)091<0099:GCEWTP>2.3.CO;2.

Springer, A. M., C. P. Mcroy, and M. V. Flint (1996), The Bering Sea Green Belt: Shelf-edge processes and ecosystem production, Fish. Oceanogr., 5, 205-223, doi:10.1111/j.1365-2419.1996.tb00118.x

Stabeno, P. J., and R. K. Reed (1992), A major circulation anomaly in the western Bering Sea, Geophys. Res. Lett., 19, 1671-1674, doi:10.1029/ 92GL01688.

Stabeno, P. J., and R. K. Reed (1994), Langrangian measurements in the Kamchatka Current and Oyashio, J. Oceanogr., 50, 653-662, doi:10.1007/BF02270498.

Stabeno, P. J., D. J. Schumacher, and K. Ohtani (1999), The physical oceanography of the Bering Sea, in Dynamics of the Bering Sea, edited by T. R. Loughlin and K. Ohtani, pp. 1-28, Univ. of Alaska Fairbanks, Fairbanks, Alaska.

Stabeno, P. J., D. G. Kachel, N. B. Kachel, and M. E. Sullivan (2005), Observations from moorings in the Aleutian passes: Temperature, salinity and transport, Fish. Oceanogr., 14, 39-54, doi:10.1111/j.13652419.2005.00362.x.

Steele, M., R. Morley, and W. Ermold (2001), PHC: A global ocean hydrograph with a high quality Arctic Ocean, J. Clim., 14, 2079-2087, doi:10.1175/1520-0442(2001)014<2079:PAGOHW>2.0.CO;2.

Takenouti, Y., and K. Y. Ohtani (1974), Currents and water masses in the Bering Sea: A review of Japanese work, in Oceanography of the Bering Sea: With Emphasis on Renewable Resources, edited by D. W. Hood and E. J. Kelley, pp. 39-58, Inst. of Mar. Sci., Univ. of Alaska, Fairbanks.
Thorpe, S. A. (1984), On the determination of $K_{v}$ in the near-surface ocean from acoustic measurements of bubbles, J. Phys. Oceanogr., 14, 855-863, doi:10.1175/1520-0485(1984)014<0855:OTDOIT $>2.0 . C O ; 2$. Thorpe, S. A. (1993), Energy loss by breaking waves, J. Phys. Oceanogr., 23, 2498-2502, doi:10.1175/1520-0485(1993)023<2498:ELBBW>2.0.CO;2.

Thorndike, A. S., D. A. Rothrock, G. A. Maykut, and R. Colony (1975), The thickness distribution of sea ice, J. Geophys. Res., 80, 4501-4513. Verkhunov, A. V., and Y. Y. Tkachenko (1992), Recent observations of variability in the western Bering Sea Current System, J. Geophys. Res., 97, 14,369-14,376

Wang, J., and M. Ikeda (1997), Diagnosing ocean unstable baroclinic waves and meanders using quasi-geostrophic equations and Q-vector method, J. Phys. Oceanogr., 27, 1158-1172, doi:10.1175/1520-0485(1997) 027<1158:DOUBWA $>2.0 . C O ; 2$.

Wang, J., and C. N. K. Mooers (1998), Three-dimensional perspectives of the Florida Current: Transport, potential vorticity, and related dynamical properties, Dyn. Atmos. Oceans, 27, 135-149, doi:10.1016/S0377-0265 (97)00004-3.

Wang, J., L. A. Mysak, and R. G. Ingram (1994), A numerical simulation of sea-ice cover in the Hudson Bay, J. Phys. Oceanogr., 24, 2515-2533, doi:10.1175/1520-0485(1994)024<2515:ANSOSI $>2.0 . \mathrm{CO} ; 2$.

Wang, J., M. Jin, V. Patrick, J. Allen, D. Eslinger, C. N. Mooers, and T. Cooney (2001), Numerical simulation of the seasonal ocean circulation patterns and thermohaline structure of Prince William Sound, Alaska, using freshwater of a line source, Fish. Oceanogr., 10, 132-148, doi:10.1046/j.1054-6006.2001.00035.x.

Wang, J., Q. Liu, and M. Jin (2002), A user's guide for a coupled ice-ocean model (CIOM) in the Pan-Arctic and North Atlantic Oceans, Tech. Rep. 02-01, 65 pp., Int. Arctic Res. Cent., Fairbanks, Alaska.

Wang, J., et al. (2003), Working toward improved small-scale sea ice-ocean modeling in the Arctic seas, Eos Trans. AGU, 84(34), doi:10.1029/ 2003EO340001.

Wang, J., B. Wu, C. C. L. Tang, J. E. Walsh, and M. Ikeda (2004), Seesaw structure of subsurface temperature anomalies between the Barents Sea and the Labrador Sea, Geophys. Res. Lett., 31, L19301, doi:10.1029/ 2004GL019981.

Wang, J., Q. Liu, M. Jin, M. Ikeda, and F. J. Saucier (2005), A coupled iceocean model in the pan Arctic and the northern North Atlantic Ocean: Simulation of seasonal cycles, J. Oceanogr., 61, 213-233, doi:10.1007/ s10872-005-0033-3

Wang, J., H. Hu, K. Mizobata, and S. Saitoh (2009), Seasonal variations of sea ice and ocean circulation in the Bering Sea: A model-data fusion study, J. Geophys. Res., 114, C02011, doi:10.1029/2008JC004727.

Williams, J. (1968), Oceanography, 242 pp., Little, Brown, New York.

Woodgate, R. A., and K. Aagaard (2005), Revising the Bering Strait freshwater flux into the Arctic Ocean, Geophys. Res. Lett., 32, L02602, doi:10.1029/2004GL021747.

Woodgate, R. A., K. Aagaard, and T. J. Weingartner (2005), Monthly temperature, salinity, and transport variability of the Bering Strait through flow, Geophys. Res. Lett., 32, L04601, doi:10.1029/2004GL021880.

Wu, B., J. Wang, and R. Zhang (2004), Effects of intraseasonal variations of the Arctic Oscillation on the Barents Sea, Polar Meteorol. Glaciol., 18, $82-95$.

Wyllie-Echeverria, T. (1995), Seasonal sea ice, the cold pool and gadid distribution on the Bering Sea Shelf, Ph.D. thesis, 281 pp., Univ. of Alaska Fairbanks, Fairbanks, Alaska.

Yao, T., C. L. Tang, and I. K. Peterson (2000), Modeling the seasonal variation of sea ice in the Labrador Sea with a coupled multicategory ice model and the Princeton ocean model, J. Geophys. Res., 105, 1153-1165. Yuan, Y., Z. Pan, and L. Sun (1991), LAGFD-WAM numerical wave mode (in Chinese with English abstract), Acta Oceanol. Sin., 10, 483-488.

Yuan, Y., F. Qiao, F. Hua, and Z. Wan (1999), The development of a coastal circulation numerical model: 1 . Wave-induced mixing and wave-current interaction (in Chinese with English abstract), J. Hydrodyn., Ser. A, 14, $1-8$.

Zimmerman, J. T. F. (1978), Topographic generation of residual circulation by oscillatory (tidal) currents, Geophys. Astrophys. Fluid Dyn., 11, 35-47, doi:10.1080/03091927808242650.

$\mathrm{H}$. $\mathrm{Hu}$, Cooperative Institute for Limnology and Ecosystems Research, School of Natural Resources and Environment, University of Michigan, 4840 S. State Road, Ann Arbor, MI 48108, USA. (hghu@umich.edu)

J. Wang (corresponding author), Great Lakes Environmental Research Laboratory, NOAA, 4840 S. State Road, Ann Arbor, MI 48108, USA. (jia.wang@noaa.gov) 